\title{
A redox-sensitive signaling pathway mediates pro-angiogenic effect of chlordecone via estrogen receptor activation
}

\author{
Eid Alabed Alibrahim ${ }^{\mathrm{a}}$, Ramaroson Andriantsitohaina ${ }^{\mathrm{a}}$, Kévin Hardonnière ${ }^{\mathrm{b}}$, Raffaella Soleti ${ }^{\mathrm{a}}$, \\ Sébastien Faure ${ }^{\mathrm{a}}$, Gilles Simard ${ }^{\mathrm{a}, \mathrm{c}, *}$ \\ a INSERM U1063, Stress Oxydant et Pathologies Métaboliques, Université d'Angers, Université Bretagne-Loire, Angers, France \\ ${ }^{\mathrm{b}}$ MINT, Univ Angers, INSERM U1066, CNRS 6021, Université Bretagne Loire, IBS-CHU, 4 Rue Larrey, F-49933 Angers, France \\ ${ }^{\mathrm{c}}$ Départment de Biochimie et Génétique, Centre Hospitalier Universitaire, Angers, France
}

\section{A R T I C L E I N F O}

\section{Keywords:}

Angiogenesis

Chlordecone

NADPH oxidase

Mitochondria

Estrogen receptor alpha

\begin{abstract}
A B S T R A C T
Aim: Chlordecone is able to induce pro-angiogenic effect through an estrogen receptor (ER $\alpha$ ) pathway involving NO release and VEGF. The present study aimed to determine the molecular mechanisms by which chlordecone promotes angiogenesis in human endothelial cells.

Results: High but not low concentration of chlordecone increased mitochondrial respiratory capacity and mitochondrial DNA content in endothelial cells. The ROS scavenger MnTMPyP was able to prevent the increase of both VEGF expression and capillary length induced by chlordecone. A significant increase of cytoplasmic $\mathrm{O}_{2} \cdot-$ production was observed after 1 and $4 \mathrm{~h}$ incubation of chlordecone, but not after $2 \mathrm{~h}$. The NADPH oxidase inhibitor apocynin or silencing p47phox prevented angiogenesis and tube formation but also the increase in production of $\mathrm{O}_{2}{ }^{-}-$at $1 \mathrm{~h}$. In addition, apocynin as well silencing p47phox prevented eNOS activation and the NO synthase inhibitor L-NAME inhibited mitochondrial $\mathrm{O}_{2}{ }^{-}{ }^{-}$production. All the previous effects of chlordecone were prevented by fulvestrant.

Conclusion: Our results indicate that an adaptation of the mitochondrial energy metabolism occurs in the chlordecone angiogenic response. Finally, we showed that chlordecone induces endothelial cells angiogenesis by a cross-talk involving NADPH oxidase and mitochondrial $\mathrm{O}_{2}{ }^{-}-$via a NO sensitive pathways through activation of ER $\alpha$. These findings propose that a molecular mechanism may partly explain the epidemiological evidence implicating chlordecone as risk factor carcinogenesis.
\end{abstract}

\section{Introduction}

Chlordecone is an organochlorine pesticide which causes significant environmental and human health concerns. The use of chlordecone on French Antilles banana plantations between 1973 and 1993 produced massive contamination of soil and river water thereby affecting largely male workers. A study carried out by Multigner et al. (Multigner et al., 2010) has clearly determined that chlordecone is associated with risk of prostate cancer in exposed individuals. Its high lipophilicity has resulted in bioaccumulation in various organisms through the food chain, and chlordecone and its metabolites have been detected in the blood, adipose tissue and prostate explaining the possible influence of this chemical on tumor development or other pathophysiological situations in which angiogenesis plays an important role (Miller, 2004; Band et al., 2011; Shakeel et al., 2010; Hillon et al., 2010). Angiogenesis, defined as the formation of new blood vessels from nearby pre-existing capillaries, represents an essential step in tumor development and metastasis (Risau, 1997). We have recently demonstrated that chlordecone exposure at concentration found in the drinking water and in the plasma of exposed patients promotes angiogenesis. Indeed, in vitro HUVEC model, chlordecone enhanced capillary-like formation through an increase in cell proliferation, migration and adhesion (Clere et al.,

\footnotetext{
Abbreviations: bFGF, basic fibroblast growth factor; CMH, 1-hydroxy-3methoxycarbonyl-2,2,5,5-tetramethylpyrolidin; EC, endothelial cell; EDTA, ethylenediaminetetraacetic acid;

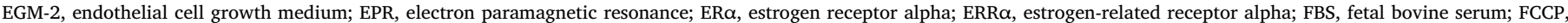

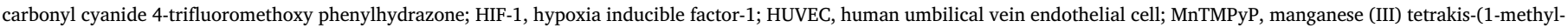

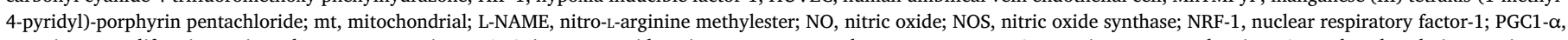

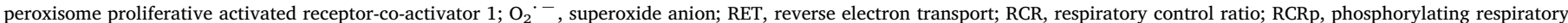

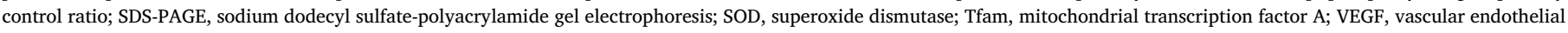
growth factor; UCR, uncoupling control ratio

* Corresponding author at: INSERM U1063, Stress Oxydant et Pathologies Métaboliques, Institut de Biologie en Santé, 4 Rue Larrey, F-49933, Angers, France.

E-mail address: gisimard@chu-angers.fr (G. Simard).
} 
2012). We have attributed this pro-angiogenic to the release of nitric oxide (NO) and to vascular endothelial growth factor (VEGF) production via an estrogen receptor alpha (ER $\alpha)$-dependent pathway. However, the precise mechanisms by which chlordecone exposure induces angiogenic effect remain to be clarified. Since reactive oxygen species (ROS) have been shown to have the capacity to regulate angiogenesis in many situations, we have tested the hypothesis that exposure to chlordecone may induce ROS production in endothelial cells (EC). As mitochondria is both a main source of ROS and a source of ATP in EC, the role of this organelle in the endergonic process caused by chlordecone has been investigated.

The low content of mitochondria in endothelial cells suggests that producing energy is not the main function of mitochondria in these cells (Kluge et al., 2013). Effectively, vessel sprouting by ECs during angiogenesis was shown to rely on glycolysis rather than on oxidative phosphorylation for ATP production (De Bock et al., 2013; Eelen et al., 2013; Cantelmo et al., 2015). Nevertheless, some studies have reported that the energetic function performed by mitochondria may play a role in the angiogenic process. For example, it was demonstrated that angiogenic signaling factors may regulate mitochondrial biogenesis (Wright et al., 2008) or mitochondrial dynamic (Lugus et al., 2011) and recently, we have observed that the in vitro angiogenic effect of a low dose red wine polyphenols was associated with an increase of mitochondrial oxidative capacity (Duluc et al., 2013). These results thus led us to consider a contribution of mitochondrial bioenergetics to chlordecone induced angiogenesis that was explored in this study.

In contrast to their limited role to supply energy, mitochondria in endothelium play an important regulatory role through the production of ROS. Mitochondria derived-ROS can activate a wide range of cellular programs including angiogenesis. For example, mitochondrial ROS production has been reported to play a crucial role in arsenic-regulated angiogenesis by stabilizing hypoxia-inducible factor (Li et al., 2014). Moreover recent evidence suggests a crosstalk between mitochondria and NADPH oxidase the other main EC source of ROS in the regulation of mitochondrial ROS production (Dikalov, 2011). For instance, NOX2 was found to induce production of mitochondrial superoxide in angiotensin II- mediated endothelial oxidative stress (Doughan et al., 2008; Dikalov et al., 2014a). Thus, the aim of the present study is to determine if chlordecone induces mitochondrial biogenesis and if a redox sensitive pathway implying a crosstalk between NADPH oxidase and mitochondria is involved in its pro-angiogenic effect in the signaling pathway. This would help identify potentially useful targets in the management of cancer subjects exposed to the organochlorine pesticide.

\section{Materials and methods}

\subsection{Chemicals}

Chlordecone (Sigma Aldrich St. Quentin Fallavier, France) was used at concentration found in the drinking water $\left(2 \times 10^{-11} \mathrm{M}\right)$ and in the plasma of exposed patients $\left(5 \times 10^{-8} \mathrm{M}\right)$ and dissolved in $0.1 \% \mathrm{di}$ methylsulfoxide cell culture medium. Superoxide dismutase (SOD) mimetic, manganese (III)tetrakis-(1-methyl-4-pyridyl)-porphyrin pentachloride (MnTMPyP), anti- $\beta$-actin antibody and inhibitors of ER (fulvestrant), NOS (nitro-L-arginine methylester, L-NAME), NADPH oxidase (apocynin), mitochondrial complexes I, III (rotenone and antimycin), mitochondrial respiration (oligomycin and antimycin A) and a decoupling agent carbonyl cyanide 4-trifluoromethoxy phenylhydrazone (FCCP) were purchased from Sigma Aldrich (St. Quentin Fallavier, France). Human VEGF, anti-VEGF, anti-p47 ${ }^{\text {phox }}$, antiphospho-eNOS-Ser1177 and anti-eNOS antibodies were from Santa Cruz Biotechnology (Santa Cruz CA). Si-RNA anti-p47 ${ }^{\text {phox }}$ and mitochondria-targeted scavenger mito-TEMPO were purchased from BD bioscience (Santa Cruz, Biotechnology). MitoNeo was gracefully provided by Prof. Richard C. Hartley and Dr. Stuart Caldwell from the
School of Chemistry, University of Glasgow.

\subsection{Cell culture}

Human umbilical vein endothelial cells (HUVECs) from newborn males were obtained from Lonza (Basel, Switzerland). The cells were cultured in plastic flasks Cellbind ${ }^{\circ}$ in endothelial cell growth medium (EGM-2) from Lonza, containing 1\% L-glutamine, 1\% streptomycin/ penicillin, $500 \mathrm{ng} / \mathrm{L}$ epidermal growth factor, $1 \mathrm{~g} / \mathrm{L}$ basic fibroblast growth factor (bFGF), supplemented with $10 \%$ fetal bovine serum (FBS) heat inactivated. The HUVECs were used from the second to fifth passage.

Cells were treated with MnTMPyP $\left(10^{-2} \mathrm{M}\right)$, fulvestrant, $\left(3 \times 10^{-8} \mathrm{M}\right)$, rotenone $\left(5 \times 10^{-6} \mathrm{M}\right)$, antimycin $\left(2.5 \times 10^{-6} \mathrm{M}\right)$, LNAME $\left(10^{-4} \mathrm{M}\right)$, apocynin $\left(10^{-4} \mathrm{M}\right)$, an inhibitor of NADPH oxidase or mitochondria targeted scavenger mito-TEMPO $\left(2.5 \times 10^{-8} \mathrm{M}\right) 30 \mathrm{~min}$ before the stimulation with chlordecone $\left(2 \times 10^{-11} \mathrm{M}\right.$ and $5 \times 10^{-8} \mathrm{M}$ ). All agents were used at concentrations at which no cytotoxicity was previously observed (Duluc et al., 2013; Mostefai et al., 2008).

\subsection{Measurement of whole cell respiration}

In order to measure the rate of respiration, the HUVECs cells were stimulated with chlordecone $\left(2 \times 10^{-11} \mathrm{M}\right.$ and $\left.5 \times 10^{-8} \mathrm{M}\right)$ in the presence or absence of fulvestrant $\left(3 \times 10^{-8} \mathrm{M}\right)$ for $24 \mathrm{~h}$. The cells were trypsinized, washed once in culture medium and centrifuged ( $500 \mathrm{~g} 5 \mathrm{~min}$ ). The pellet was resuspended in respiratory medium EGM2. Mitochondrial oxygen consumption was recorded at $37^{\circ} \mathrm{C}$ using a high-resolution oxygraph-2 $\mathrm{K}$ respirometer (Oroboros, Innsbruk, Austria). The measurement of basal respiration, non-phosphorylating respiration, the ability of the respiratory chain without regulation performed by the ATP synthase, the respiratory control ratio (RCR), the phosphorylating respiratory control ratio (RCRp) and the uncoupling control ratio (UCR) were performed as described by Duluc. (Duluc et al., 2013).

\subsection{RNA extraction and quantitative PCR analysis ( $q P C R$ )}

After treatment, total RNA was isolated form cells using RNA extraction kit Macherey-Nagel (Hoerdt, France). The quantification of gene expression of peroxisome proliferative activated receptor-co-activator 1 (PGC1- $\alpha$ ), estrogen-related receptor alpha (ERR $\alpha)$, the nuclear respiratory factor-1 (NRF-1), mitochondrial transcription factor A (Tfam) were performed as previously described by (Duluc et al., 2013).

\subsection{Quantification of the mitochondrial DNA content}

After treatment, total DNA was isolated from endothelial cells. The mitochondrial DNA (mtDNA) copy number was determined by qPCR as previously described by (Duluc et al., 2013).

\subsection{In vitro capillary network formation on ECM gel $^{\infty}$}

After $24 \mathrm{~h}$ incubation with chlordecone $\left(2 \times 10^{-11} \mathrm{M}\right.$ and $\left.5 \times 10^{-8} \mathrm{M}\right)$ in the presence or absence of apocynin $\left(10^{-4} \mathrm{M}\right)$, MnTMPyP $\left(10^{-2} \mathrm{M}\right)$ and mito-TEMPO $\left(2.5 \times 10^{-8} \mathrm{M}\right)$, HUVECs were detached with trypsin ethylenediaminetetraacetic acid (EDTA). The cells were seeded with a density of $1.5 \times 10^{5}$ cells per well precoated with ECM gel ${ }^{\circ}$ (Sigma-Aldrich). Briefly, $1.5 \times 10^{-4} \mathrm{~L}^{\text {of }} \mathrm{ECM}^{\circ}$ was added into a four-well plate and allowed to solidify for $1 \mathrm{~h}$ at $37^{\circ} \mathrm{C}$. Then, cells are incubated with medium containing 10\% FBS and allowed to adhere for $1 \mathrm{~h}$ after which the different stimuli were added. Tube formation was examined by phase-contrast microscopy (MOTIC AE21) after $24 \mathrm{~h}$ and average length of capillaries was quantified using ImageJ software for evaluation of angiogenesis. 
A.

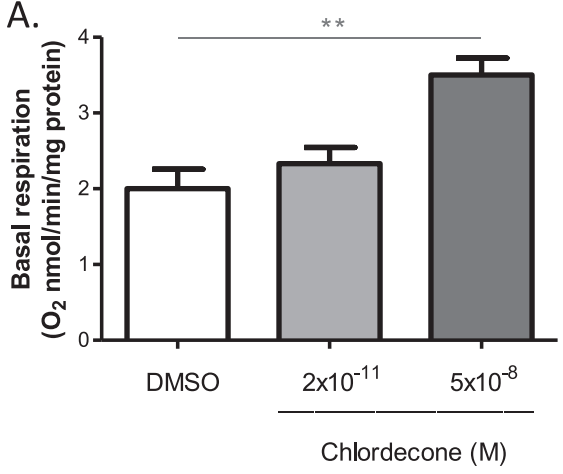

C.

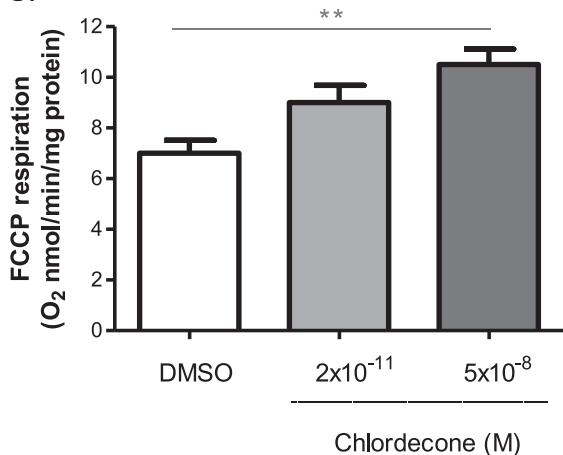

E.

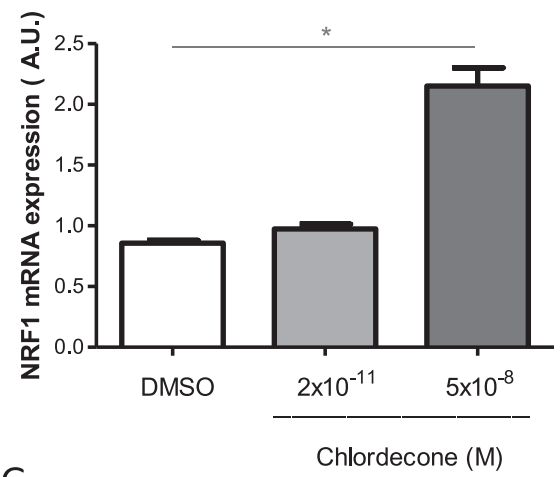

G.

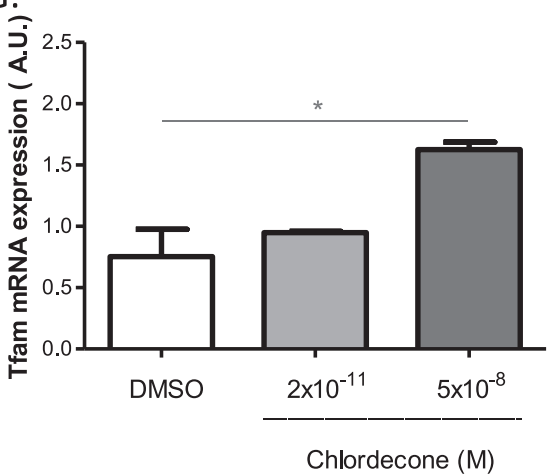

B.

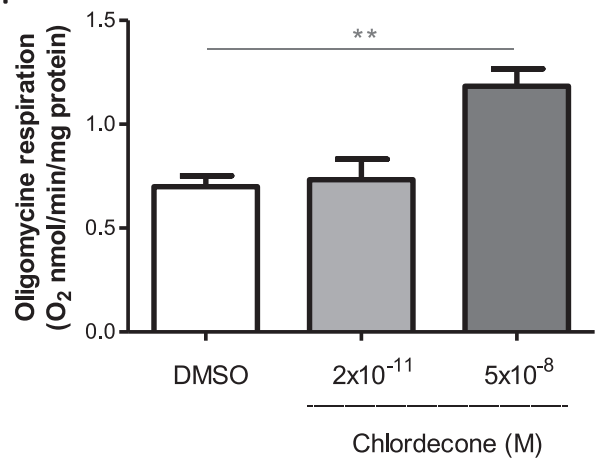

D.

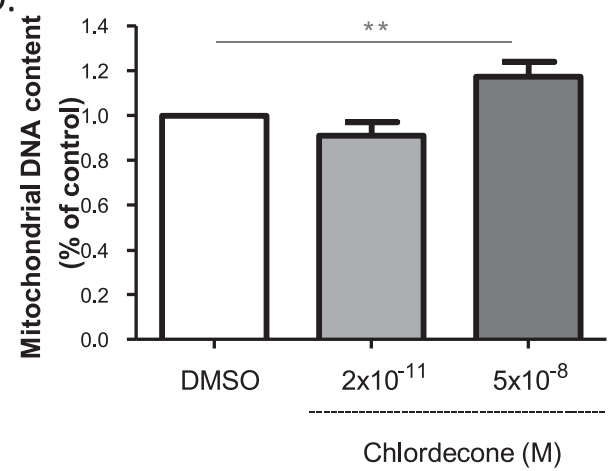

F.

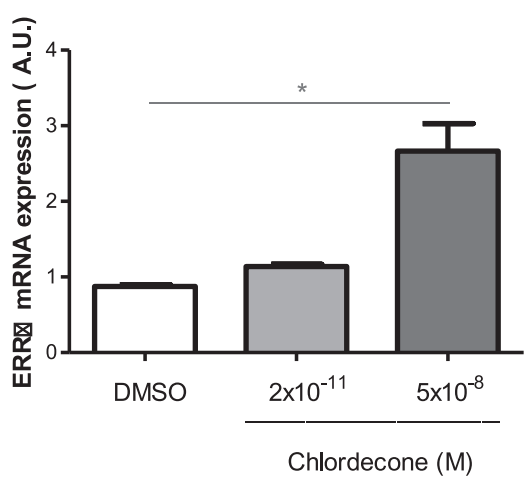

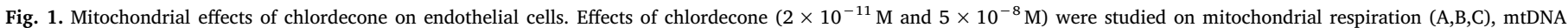

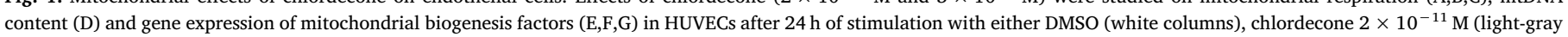
columns) or $5 \times 10^{-8} \mathrm{M}$ (dark-gray columns). Data are means \pm SEM of eight independent experiments. ${ }^{*} \mathrm{p}<0.05$ versus DMSO. ${ }^{* *} \mathrm{p}<0.01$ versus DMSO.

\subsection{Western blot}

After treatment with chlordecone $\left(2 \times 10^{-11} \mathrm{M}\right.$ and $\left.5 \times 10^{-8} \mathrm{M}\right)$ in the presence or absence of apocynin $\left(10^{-4} \mathrm{M}\right)$, L-NAME $\left(10^{-4} \mathrm{M}\right)$, siRNAp47phox and MnTMPyP $\left(10^{-2} \mathrm{M}\right)$, mito-TEMPO $\left(2.5 \times 10^{-8} \mathrm{M}\right)$, the cells were homogenized, washed twice with PBS and trypsinized. The cells were lysed by RIPA buffer with the following composition: $\left(2 \times 10^{-2} \mathrm{M}\right.$ Tris-HCL $(\mathrm{pH} 7.5), 1.5 \times 10^{-1} \mathrm{M} \mathrm{NaCl}, 10^{-3} \mathrm{M} \mathrm{Na}_{2}$ EDTA, $10^{-3} \mathrm{M}$ EGTA, $1 \%$ NP-40, 0,5\% sodium deoxycholate, $2.5 \times 10^{-3} \mathrm{M}$ sodium pyrophosphate, $10^{-3} \mathrm{M} \beta$-glycerophosphate, $10^{-3} \mathrm{M} \mathrm{Na}_{3} \mathrm{VO}_{4}$ ) in presence of protease inhibitor. Cells were allowed to lyse for $45 \mathrm{~min}$ on ice and centrifuged at $15000 \mathrm{~g}$ for $15 \mathrm{~min}$ at $4{ }^{\circ} \mathrm{C}$. The supernatant was removed, and protein concentrations in the supernatant were determined by protein assay. 
The proteins $\left(30 \times 10^{-6} \mathrm{~g}\right)$ were separated on $10 \%$ sodium dodecyl sulfate-polyacrylamide gel electrophoresis (SDS-PAGE) and transferred on the nitrocellulose membranes. The membranes were incubated with anti-VEGF, anti-p47 $7^{\text {phox }}$, anti-phospho-eNOS-Ser1177 and anti-eNOS antibodies overnight at $4{ }^{\circ} \mathrm{C}$. The anti- $\beta$-actin (Sigma-Aldrich) was used to visualize protein gel loading. The membranes were then incubated with appropriate horseradish peroxidase-conjugated secondary antibody. The protein-antibody complexes were detected by chemiluminescence using the Western Blotting Luminol reagent kit (Santa Cruz Biotechnology ${ }^{\circ}$ ).

\subsection{Superoxide anion $\left(\mathrm{O}_{2}{ }^{-}\right)$quantification by electron paramagnetic resonance (EPR)}

For $\mathrm{O}_{2} \cdot-$ quantification, cells were treated with chlordecone $\left(2 \times 10^{-11} \mathrm{M}\right.$ and $\left.5 \times 10^{-8} \mathrm{M}\right)$ for 1,2 and $4 \mathrm{~h}$ in the presence or absence of apocynin $\left(10^{-4} \mathrm{M}\right)$, L-NAME $\left(10^{-4} \mathrm{M}\right)$, rotenone $\left(5 \times 10^{-6} \mathrm{M}\right)$, antimycin $\left(2.5 \times 10^{-6} \mathrm{M}\right)$, siRNAp47 ${ }^{\text {phox }}$ and fulvestrant $\left(3 \times 10^{-8} \mathrm{M}\right)$. Cells were allowed to equilibrate in deferoxaminechelated Krebs-Hepes solution containing 1-hydroxy-3methoxycarbonyl-2,2,5,5-tetramethylpyrolidin (CMH; Noxygen, Mainz, Germany) $\left(5 \times 10^{-4} \mathrm{M}\right)$, deferoxamine $\left(2.5 \times 10^{-5} \mathrm{M}\right)$, and DETC (sodium diethyl thiocarbamate trihydrate $\left(5 \times 10^{-6} \mathrm{M}\right)$ under constant temperature $\left(37^{\circ} \mathrm{C}\right)$ for $45 \mathrm{~min}$. Cells were then scrapped, frozen in plastic tubes and then analyzed by EPR spectroscopy. Values are expressed as units $/ \mu \mathrm{g} . \mu \mathrm{L}$ of proteins.

\subsection{Detection of mitochondrial superoxide anion (mtROS) by confocal microscopy}

For detection of cells were treated with chlordecone $\left(2 \times 10^{-11} \mathrm{M}\right.$ and $5 \times 10^{-8} \mathrm{M}$ ) at 1 and $4 \mathrm{~h}$ in the presence or absence of apocynin $\left(10^{-4} \mathrm{M}\right)$, L-NAME $\left(10^{-4} \mathrm{M}\right)$, siRNAp47 $7^{\text {phox }}$ and fulvestrant $\left(3 \times 10^{-8} \mathrm{M}\right)$. Cells were washed twice with PBS and incubated in Krebs containing $5 \times 10^{-6} \mathrm{M}$ Mitosox ${ }^{\circ}$ red (a marker for mitochondrial $\mathrm{O}_{2}{ }^{-}$) for $10 \mathrm{~min}$, and then the cells were fixed by $4 \%$ paraformaldehyde during $15 \mathrm{~min}$ incubation at $37^{\circ} \mathrm{C}$. The cells were incubation with DAPI blue $3.6 \times 10^{-6} \mathrm{M}$ (a marker of the nucleus) at room temperature for $15 \mathrm{~min}$. The wavelengths of excitation and emission are $510 / 580 \mathrm{~nm}$ and 340/488 for Mitosox and DAPI respectively. The images obtained by confocal microscopy were imported into the image $\mathrm{J}$ software and the density of the fluorescence was analyzed.

In some experiments, mitochondrial levels of anion superoxide were measured using the MitoNeoD probe) (Shchepinova et al., 2017). MitoNeo was extemporaneously reduced to MitoNeoD before each experiment as previously described. Cells were loaded with $10 \times 10^{-6} \mathrm{M}$ MitoNeoD for $45 \mathrm{~min}$, and were then treated with chlordecone $\left(2 \times 10^{-11} \mathrm{M}\right.$ and $\left.5 \times 10^{-8} \mathrm{M}\right)$ for 1 or $4 \mathrm{~h}$ in presence or absence of $2.5 \times 10^{-8} \mathrm{M}$ of the mitochondria-targeted antioxidant MitoTempo $\left(2.5 \times 10^{-8} \mathrm{M}\right)$ (Sigma-Aldrich). Reaction of MitoNeoD with $\mathrm{O}_{2}{ }^{--}$ generates MitoNeoOH. Thus, MitoNeoOH formation was directly monitored by recording the fluorescence intensity on a Clariostar spectrofluorimeter microplate reader (BMG LabTech), using $544 \mathrm{~nm}$ excitation and $605 \mathrm{~nm}$ emission wavelengths.

\subsection{Statistical analysis}

Data are presented as mean \pm SEM, $\mathrm{n}$ represents the number of experiments repeated at least in triplicate. Statistical analyses were performed by ANOVA followed by a Bonferroni test. p $<0.05$ was considered to be statistically significant.

\section{Results}

\subsection{High but not low concentration of chlordecone increases mitochondrial biogenesis}

Mitochondrial respiration was studied after stimulation of HUVECs with both chlordecone concentrations for $24 \mathrm{~h}$. Chlordecone at low concentration did not significantly modify the basal, oligomycin and FCCP-sensitive respirations. We only observed a trend of increasing maximal oxygen consumption upon addition of the uncoupler FCCP (Fig. 1A-C). However, chlordecone at high concentration increased basal, oligomycin and FCCP-sensitive respirations (Fig. 1A-C). The increase in mitochondrial respiration by high chlordecone concentration was not associated with changes in different ratios, RCR, RCRp and UCR (not shown), indicating that this concentration of chlordecone probably increased mitochondrial mass. To confirm this, mtDNA content was quantified. High but not low concentration of chlordecone increased the mtDNA content in ECs (Fig. 1D).

To determine whether the increase of mitochondrial mass induced by high chlordecone concentration was associated with an increased mitochondrial biogenesis, the expression of genes implicated in mitochondrial biogenesis was explored using qPCR $24 \mathrm{~h}$ after exposure. Gene expression of PGC1 $\alpha$ downstream transcription factors was only detected in these cells. If low concentration chlordecone did not modulate the expression of NRF1, ERR $\alpha$ and Tfam, high chlordecone concentration increased their expression (Fig. 1E-G). Collectively, these results suggest that endothelial cells adapt their mitochondrial energy metabolism when shifting from quiescence to rapid growth during angiogenesis.

\subsection{Chlordecone promotes angiogenesis in a MnTMPyP-sensitive manner}

As ROS have been identified as playing a role in various signaling pathways in endothelial cells, including angiogenesis, we next determined whether ROS were implicated in the pro-angiogenic effect of chlordecone. As shown in Fig. 2A and B, the ROS scavenger MnTMPyP $\left(10^{-2} \mathrm{M}\right)$, did not have an effect when added alone but it was able to prevent the increase of both VEGF expression and capillary length induced by chlordecone $\left(2 \times 10^{-11} \mathrm{M}\right.$ and $\left.5 \times 10^{-8} \mathrm{M}\right)$. These results suggest that chlordecone induces angiogenesis by a ROS dependent mechanism.

\subsection{Chlordecone promotes angiogenesis through a sequential regulation of cytoplasmic and mitochondrial $\mathrm{O}_{2}{ }^{-}$production}

To identify the source of ROS implicated in the pro-angiogenic effect of chlordecone, production of cytoplasmic and mitochondrial ROS were measured after treatment of HUVECs with chlordecone $\left(2 \times 10^{-11} \mathrm{M}\right.$ and $\left.5 \times 10^{-8} \mathrm{M}\right)$ at different time points $(1,2$, and $4 \mathrm{~h})$. Cytoplasmic $\mathrm{O}_{2}{ }^{-}-$, were quantified using EPR. A significant increase of cytoplasmic $\mathrm{O}_{2} \cdot{ }^{-}$production was observed at 1 and $4 \mathrm{~h}$ (Fig. $3 \mathrm{~A}$ and C). Chlordecone $\left(2 \times 10^{-11} \mathrm{M}\right.$ and $\left.5 \times 10^{-8} \mathrm{M}\right)$ didn't modulate the production of cellular $\mathrm{O}_{2}{ }^{-}-$at $2 \mathrm{~h}$ (Fig. 3B). Mitochondrial $\mathrm{O}_{2}{ }^{-}-$levels were evaluated with both the generally used mitochondria-specific fluorescent probe MitoSOX (Fig. 3D and E) and also with MitoNeoD, a new probe, recently developed to limit probe intercalation in the DNA (Fig. 3F and G). Even if, as reported, the increase fluorescence upon oxidative of mitoNeoD is less than for MitoSOX) (Shchepinova et al., 2017), results going in the same direction with both probes were observed suggesting that mitochondria are involved in the $\mathrm{O}_{2}{ }^{-}$production at $4 \mathrm{~h}$ but not at $1 \mathrm{~h}$ or $2 \mathrm{~h}$ (data not shown). In addition, the effect of chlordecone on mitoNeoD fluorescence at $1 \mathrm{~h}$ and at $4 \mathrm{~h}$ was evaluated on cells initially preincubated with mito-TEMPO. As reported in Fig. $3 \mathrm{~F}$ and $\mathrm{G}$, the pretreatment with the mitochondria targeted scavenger was able to prevent the increase in fluorescence of MitoNeoD observed at $4 \mathrm{~h}$ without affecting the fluorescence at $1 \mathrm{~h}$ confirming the 
A.
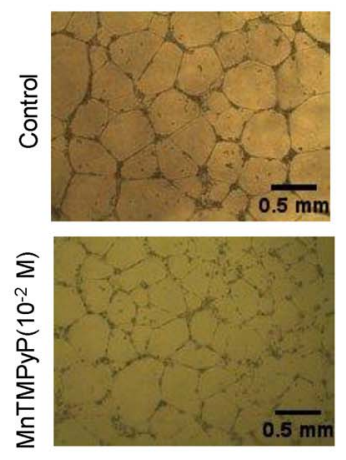

DMSO
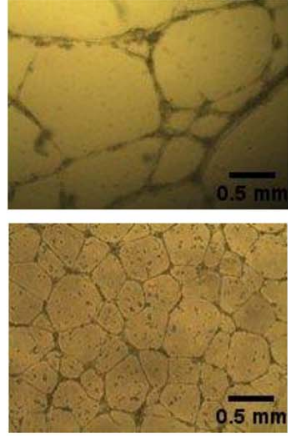

Chlordecone $\left(2 \times 10^{-11} \mathrm{M}\right)$
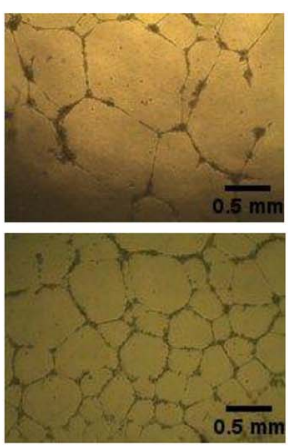

Chlordecone

$\left(5 \times 10^{-8} \mathrm{M}\right)$

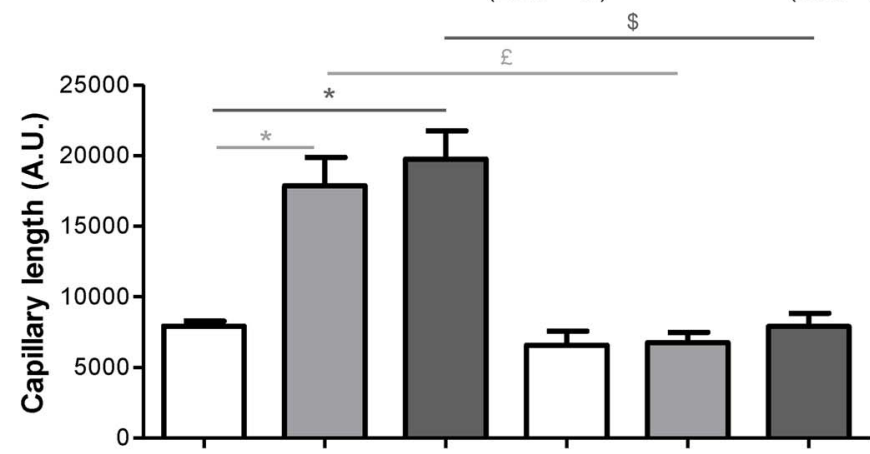

Chlordecone (M) DMSO $\quad 2 \times 10^{-11} \quad 5 \times 10^{-8} \quad$ DMSO $\quad 2 \times 10^{-11} \quad 5 \times 10^{-8}$

$\begin{array}{lllllll}\operatorname{MnTMPyP}(\mathrm{M}) & 0 & 0 & 0 & 10^{-2} & 10^{-2} & 10^{-2}\end{array}$

B.

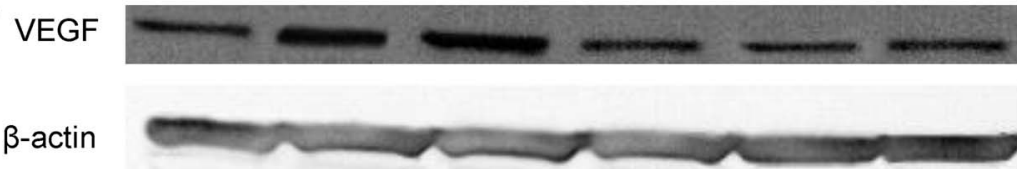

$21 \mathrm{KDa}$

$40 \mathrm{KDa}$
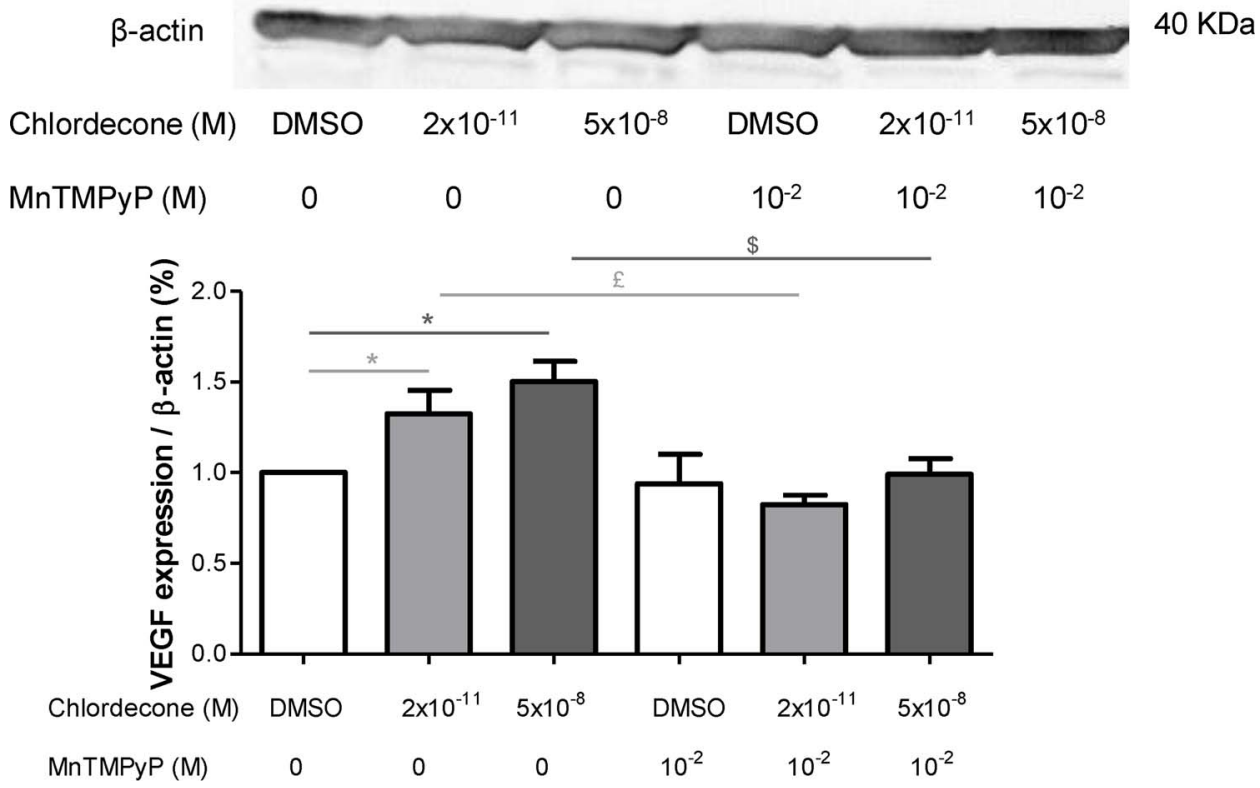

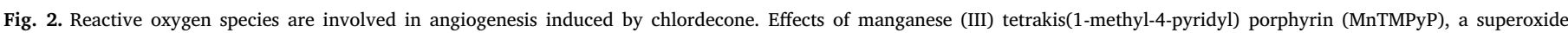

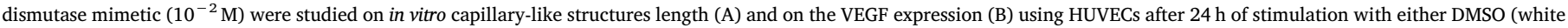

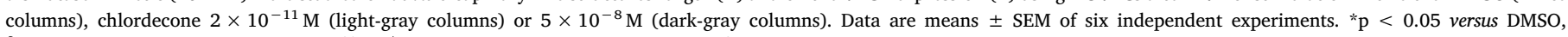
${ }^{f_{\mathrm{p}}}<0.05$ versus chlordecone $2 \times 10^{-11} \mathrm{M},{ }^{\$} \mathrm{p}<0.05$ versus chlordecone $5 \times 10^{-8} \mathrm{M}$. 


\section{A: $1 \mathrm{~h}$}

B: $2 h$
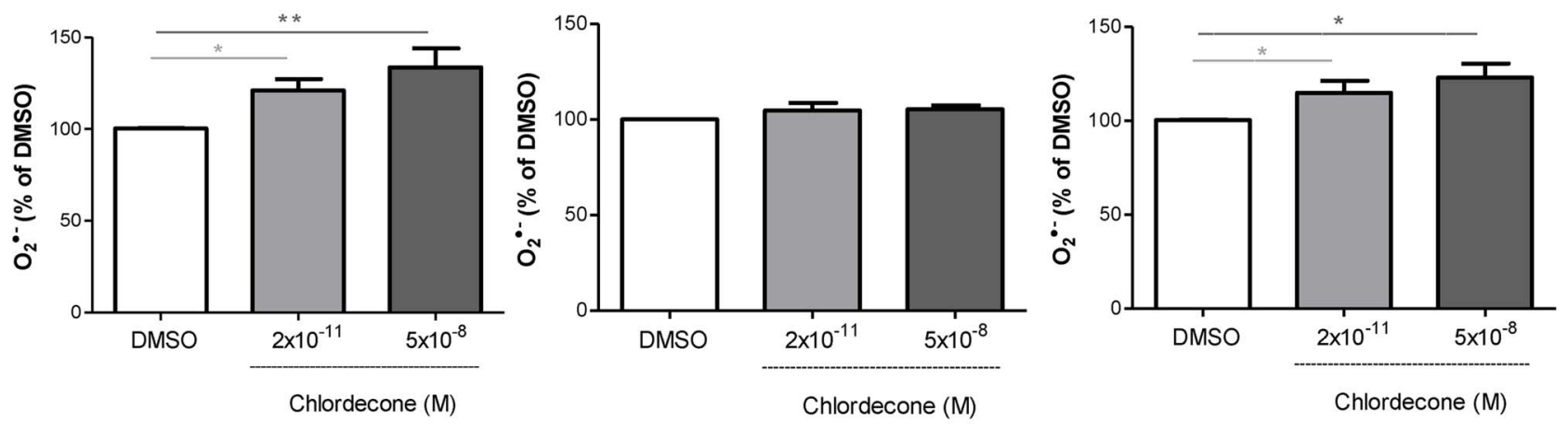

$\mathrm{D}: 1 \mathrm{~h}$
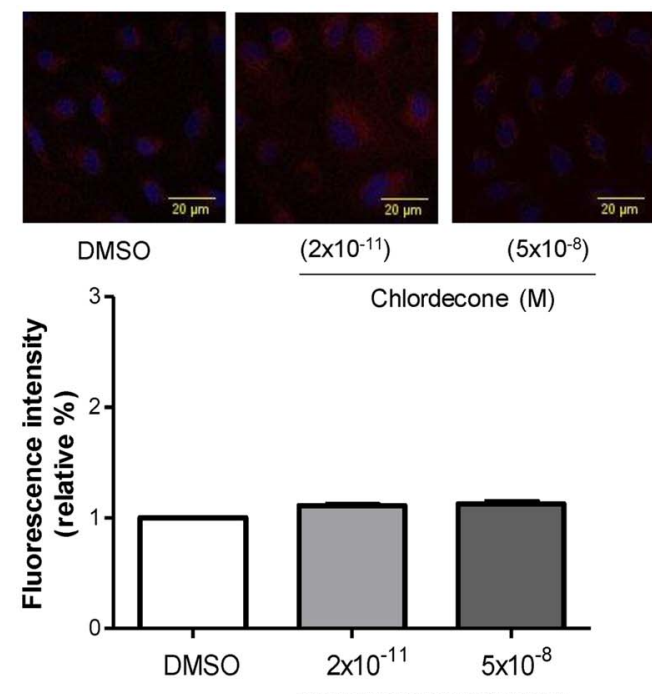

Chlordecone (M)
E: $4 \mathrm{~h}$
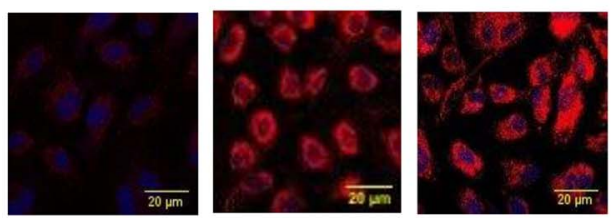

DMSO

$\left(2 \times 10^{-11}\right)$

$\left(5 \times 10^{-8}\right)$

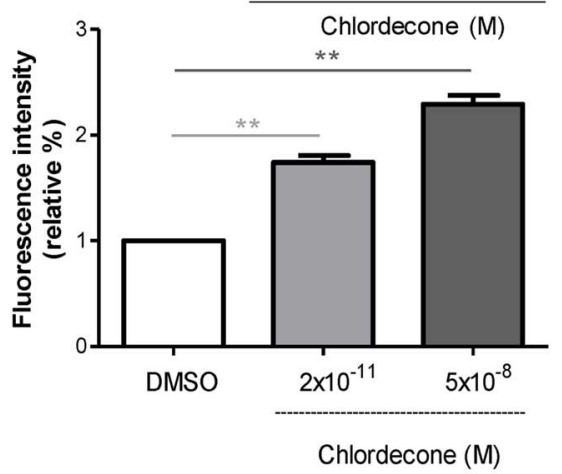

$\mathrm{G}: 4 \mathrm{~h}$

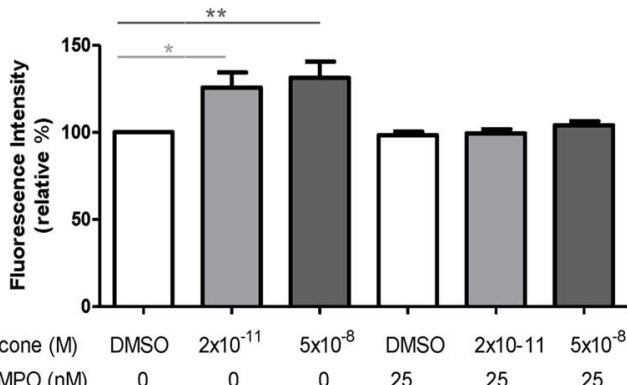

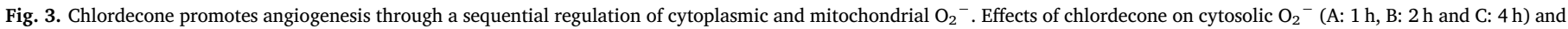

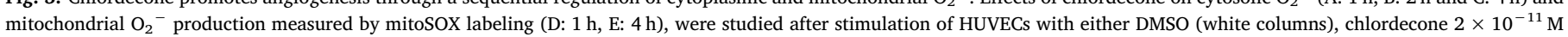

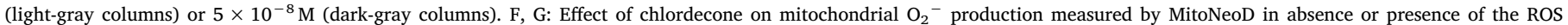
scavenger Mito-TEMPO. Data are means \pm SEM of six independent experiments with mitoSOX and four with MitoNeoD. * $\mathrm{p}<0.05$ versus DMSO, ** $\mathrm{p}<0.01$ versus DMSO.

mitochondrial origin of the $\mathrm{O}_{2}{ }^{-}-$production at $4 \mathrm{~h}$.

3.4. Pro-angiogenic effect of chlordecone is regulated by $\mathrm{O}_{2} \cdot{ }^{-}$production from NADPH oxidase

NADPH oxidase is an important source of early ROS production in endothelial cells (Fig. 3F and G) (Dikalov et al., 2014b; Ushio-Fukai, 2006; Frey et al., 2009);. Thus, the cytoplasmic $\mathrm{O}_{2}{ }^{-}$production at $1 \mathrm{~h}$ induced by both chlordecone concentrations could be related to NADPH oxidase activity. To test this possibility, the production of cellular $\mathrm{O}_{2} \cdot{ }^{-}$ was monitored by EPR in the presence of apocynin $\left(10^{-4} \mathrm{M}\right)$ an inhibitor of NADPH oxidase (Fig. 4A). As previously described, (Johnson 
A.

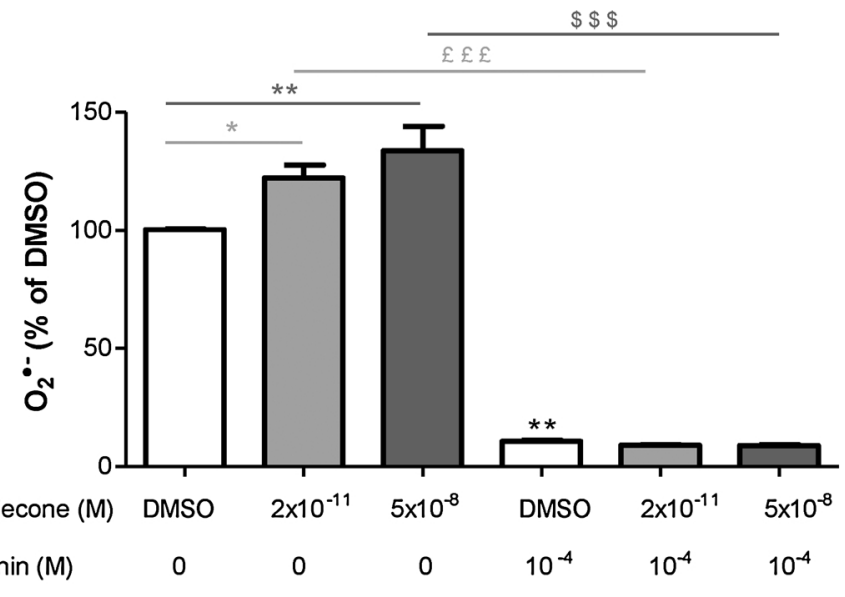

Fig. 4. Effects of inhibitors of ROS sources on $\mathrm{O}_{2}{ }^{-}$ production after $1 \mathrm{~h}$ of chlordecone exposition. Effects of NADPH oxidase inhibitor apocynin $\left(10^{-4} \mathrm{M}\right)$ (A), of inhibitors of mitochondrial respiratory chain rotenone $\left(5 \times 10^{-6} \mathrm{M}\right)$ and antimycin $\left(2.5 \times 10^{-6} \mathrm{M}\right) \quad$ (B), of siRNA p47phox $\left(5 \times 10^{-8} \mathrm{M}\right)(\mathrm{C})$ on cytosolic $\mathrm{O}_{2}{ }^{-}$production at $1 \mathrm{~h}$ were studied on HUVECs stimulated by either DMSO (white columns), chlordecone $2 \times 10^{-11} \mathrm{M}$ (lightgray columns) or $5 \times 10^{-8} \mathrm{M}$ (dark-gray columns). Cytosolic $\mathrm{O}_{2}{ }^{-}$was measured by EPR. Data are means \pm SEM of $\mathrm{n}=6$ or $\mathrm{n}=4$ for mitochondrial inhibition experiments * $\mathrm{p}<0.05$ versus DMSO, ** $\mathrm{p}<0.01$ versus DMSO, $\mathrm{Ep}<0.05$ versus chlordecone $2 \times 10^{-11} \mathrm{M} ; £ £ £ \mathrm{p}<0.001$ versus chlordecone $2 \times 10^{-11} \mathrm{M}, \quad \$ \$ \$ \mathrm{p}<0.001$ versus chlordecone $5 \times 10^{-8}$.

B.

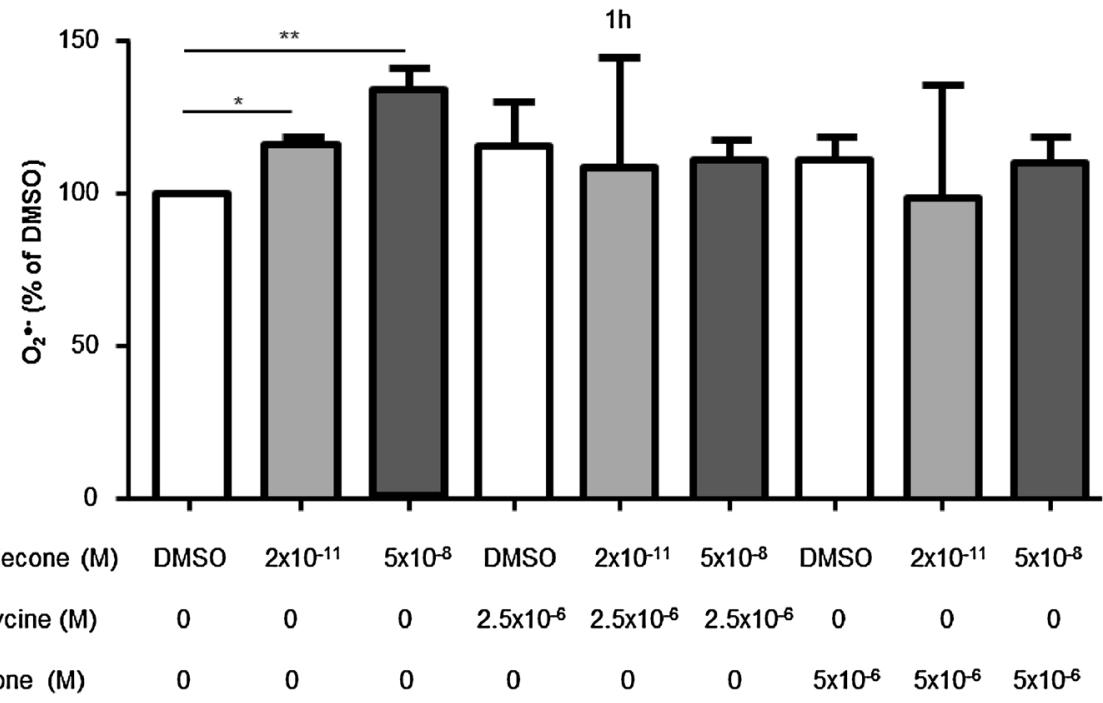

C.

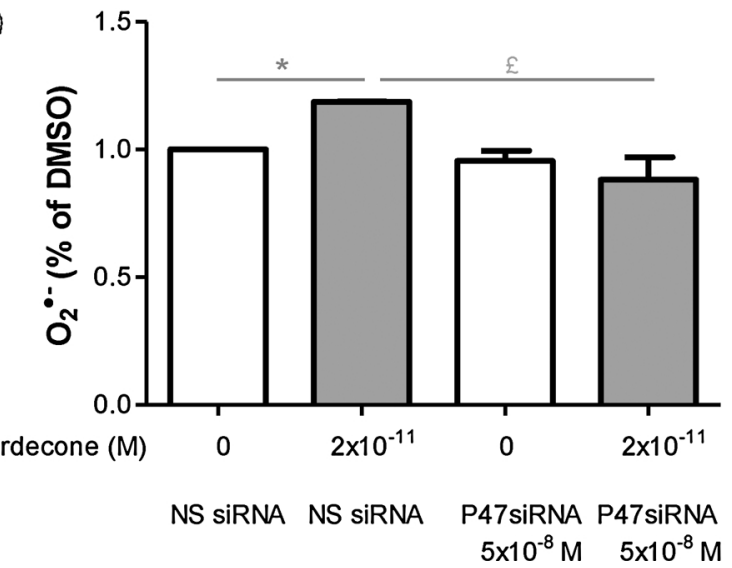

et al., 2002), apocynin reduced the basal cytoplasmic $\mathrm{O}_{2}{ }^{-}$- production. Apocycin was also able to prevent the increase in production of cellular $\mathrm{O}_{2}{ }^{-}-$induced by both concentrations of chlordecone. Moreover, rotenone and antimycin, inhibitor respectively of the complex I and III of the respiratory chain equally blocked the early ROS production (Fig. 4B).

It has been reported that the key post-translational modifications involved in oxidase activation of Nox1/2, are the phosphorylation of p $47^{\text {phox }}$ (Frey et al., 2009). To confirm that Nox was the major source of $\mathrm{O}_{2}{ }^{-}$- production in our cellular model, p47phox was silenced with a specific siRNA $72 \mathrm{~h}$ before cells exposition to chlordecone. As evidenced in Fig. 4C, silencing p47phox abrogated chlordecone-stimulated production of cytoplasmic $\mathrm{O}_{2} \cdot{ }^{-}$at one hour confirming that Nox1/2 was the major source of chlordecone-induced cytoplasmic $\mathrm{O}_{2}{ }^{-}-$at this time.

To evaluate the involvement of $\mathrm{O}_{2}{ }^{-}$- production by NADPH oxidase in the process of the formation of capillaries, we assayed VEGF expression and capillary formation in the presence or absence apocynin $\left(10^{-4} \mathrm{M}\right)$ for $24 \mathrm{~h}$ (Fig. $5 \mathrm{~A}$ and B). Apocynin $\left(10^{-4} \mathrm{M}\right)$ prevented the increase in length of capillary and synthesis of VEGF induced by chlordecone $\left(2 \times 10^{-11} \mathrm{M}\right.$ and $\left.5 \times 10^{-8} \mathrm{M}\right)$ suggesting that $\mathrm{O}_{2} \cdot-$ derived from NADPH oxidase played a key role in the pro-angiogenic 
A.
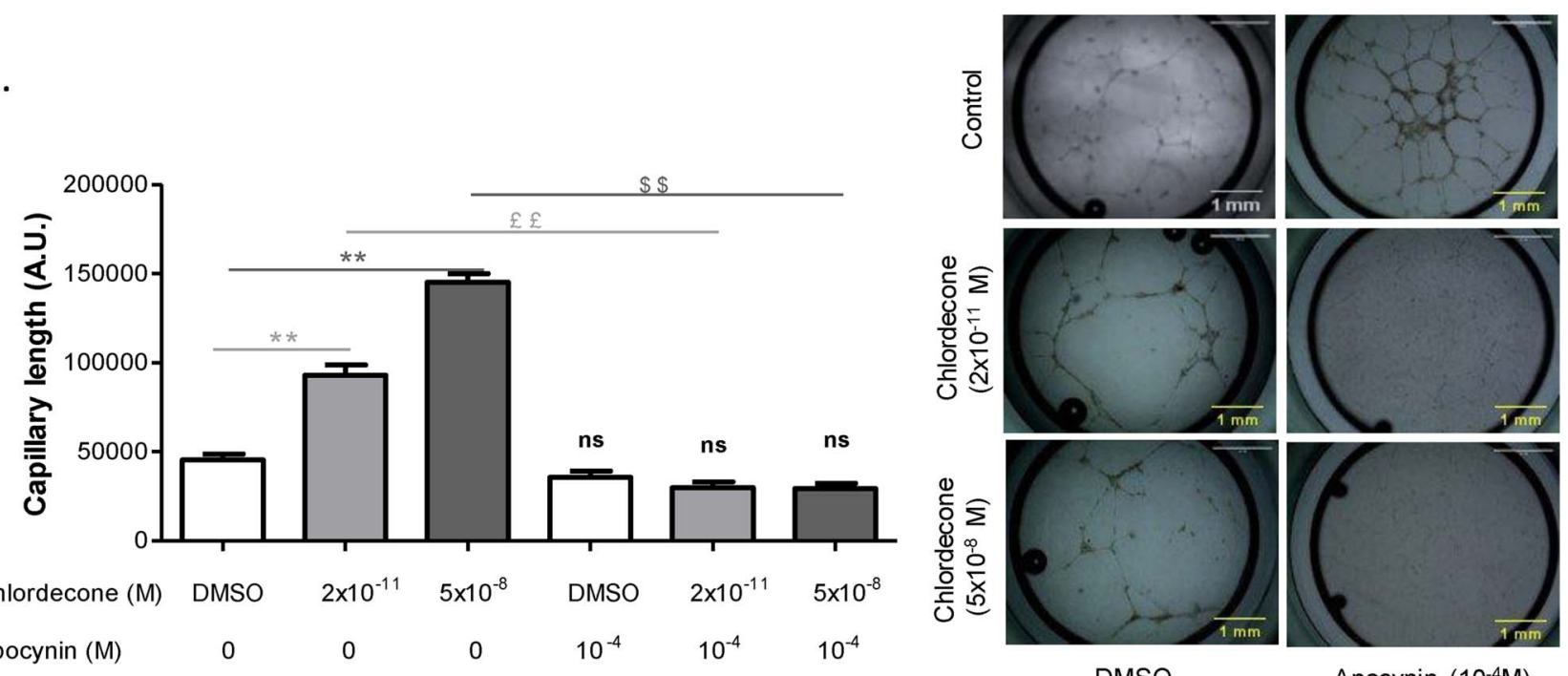

DMSO

Apocynin $\left(10^{-4} \mathrm{M}\right)$

B.

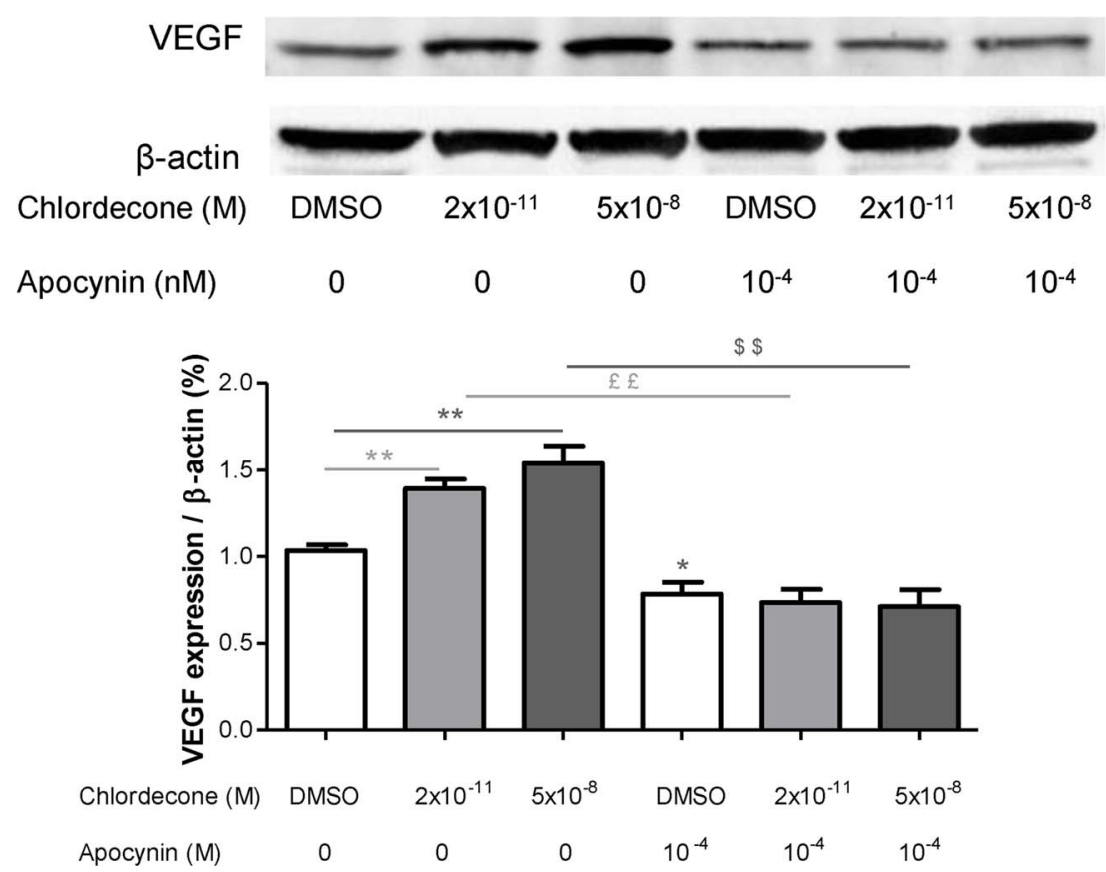

$21 \mathrm{KDa}$

$40 \mathrm{KDa}$

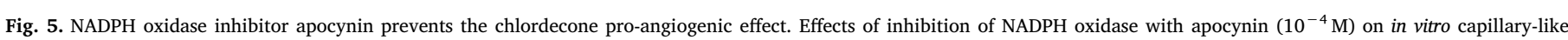

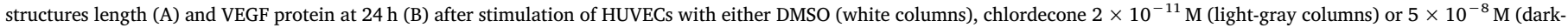

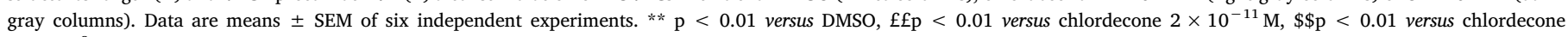
$5 \times 10^{-8} \mathrm{M}$.

effect of chlordecone.

3.5. Chlordecone promotes angiogenesis by regulating the production of mitochondrial $\mathrm{O}_{2} \cdot{ }^{-}$through NADPH oxidase and NOS inhibitor-sensitive mechanisms

We therefore aimed to determine if NADPH oxidase would contribute to chlordecone-induced mitochondrial $\mathrm{O}_{2}{ }^{-}{ }^{-}$. Apocynin as well silencing p47phox prevented the increase in MitoSOX fluorescence signal in chlordecone-stimulated HUVECs (Fig. 6A and B) confirming that chlordecone $\left(2 \times 10^{-11} \mathrm{M}\right.$ and $\left.5 \times 10^{-8} \mathrm{M}\right)$ induced mitochondrial $\mathrm{O}_{2}{ }^{-}-$production via an axis NADPH oxidase $\mathrm{O}_{2}{ }^{-}{ }^{-}$-release-mitochondrial $\mathrm{O}_{2} \cdot-$.

Chlordecone $\left(2 \times 10^{-11} \mathrm{M}\right.$ and $\left.5 \times 10^{-8} \mathrm{M}\right)$ has also been shown to promote NO production by increasing eNOS phosphorylation on its activator site (Ser-1177). To assess the involvement of eNOS in this redox signalisation, the production of cytoplasmic and mitochondrial $\mathrm{O}_{2} \cdot{ }^{-}$was measured in the presence of L-NAME $\left(10^{-4} \mathrm{M}\right)$, an inhibitor of NOS (Fig. 7A-C). $\mathrm{O}_{2}{ }^{-}-$production at one hour was not affected by LNAME in contrast to production of cytoplasmic $\mathrm{O}_{2}{ }^{-}$and mitochondrial $\mathrm{O}_{2}{ }^{-}-$at $4 \mathrm{~h}$ which were prevented. These results were consistent with a role of NOS to stimulate mitochondrial $\mathrm{O}_{2}{ }^{-}$- production. Furthermore, apocynin pretreatment inhibited the increase eNOS ser1177 phosphorylation induced by chlordecone (Fig. 7D). Finally, increasing VEGF expression induced by chlordecone $\left(2 \times 10^{-11} \mathrm{M}\right.$ and $5 \times 10^{-8} \mathrm{M}$ ) was prevented by treatment of HUVECs with L-NAME, an inhibitor of NOS (Fig. 7E). Taken together, these results suggest that pro-angiogenic effect of chlordecone $\left(2 \times 10^{-11} \mathrm{M}\right.$ and $\left.5 \times 10^{-8} \mathrm{M}\right)$ depends on eNOS activity which was activated by NADPH oxidase-derived-ROS. Altogether the results led us to suggest-that chlordecone promotes angiogenesis by regulating the production of mitochondrial $\mathrm{O}_{2}{ }^{-}-$through NADPH oxidase and eNOS activation. 
A.
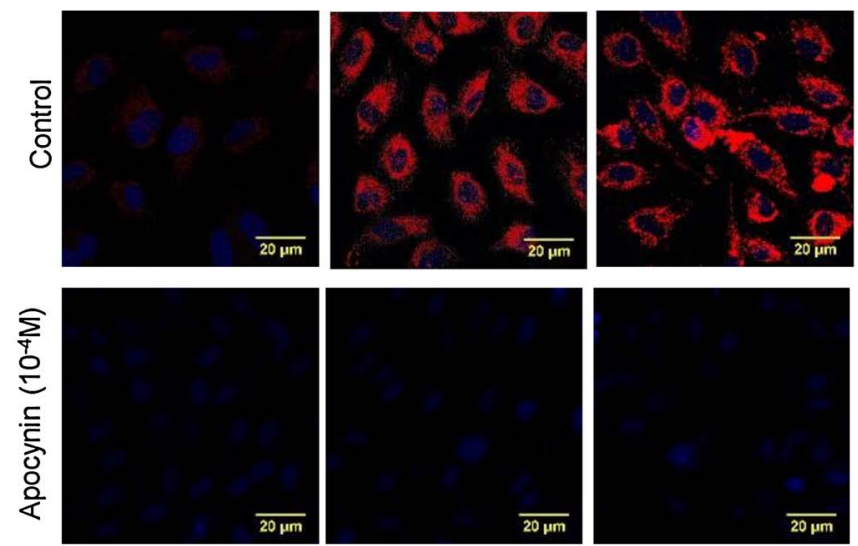

DMSO

$\left(2 \times 10^{-11}\right)$
Chlordecone (M)

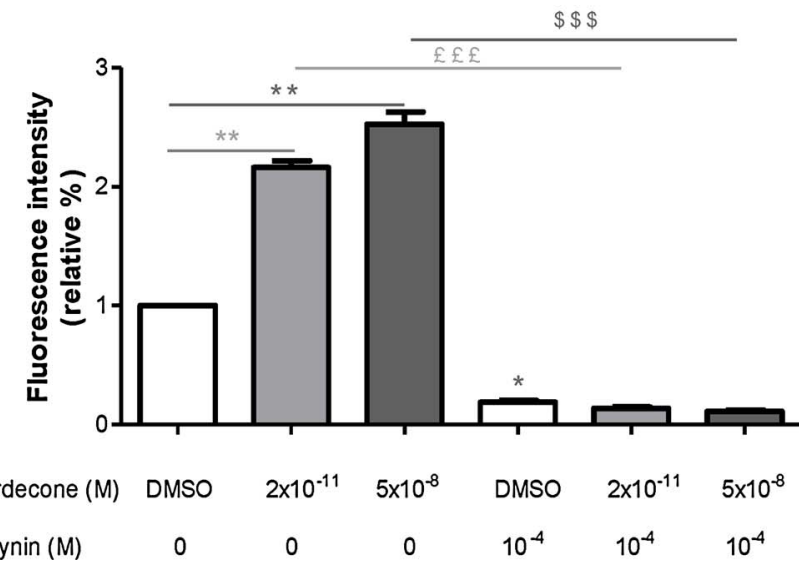

B.
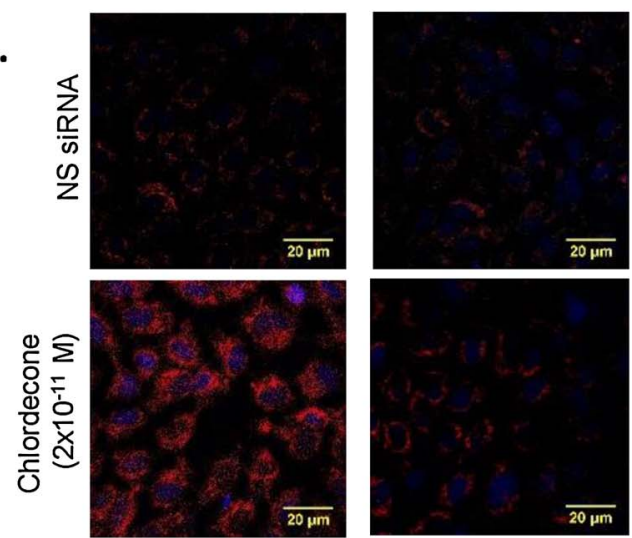

DMSO p47phox

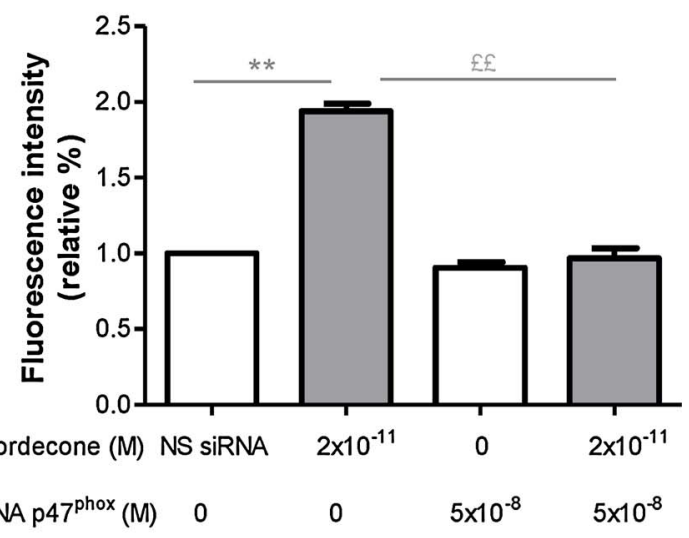

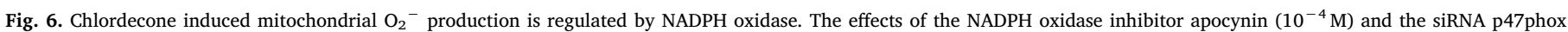

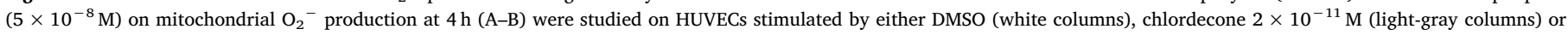

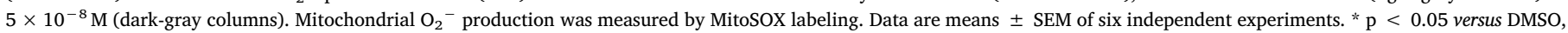
${ }^{* *} \mathrm{p}<0.01$ versus DMSO, $\mathrm{£} \mathrm{p}<0.01$ versus chlordecone $2 \times 10^{-11} \mathrm{M}, £ £ £ \mathrm{p}<0.001$ versus chlordecone $2 \times 10^{-11} \mathrm{M}$, $\$ \$ \$ \mathrm{p}<0.001$ versus chlordecone $5 \times 10^{-8} \mathrm{M}$.

\subsection{Mito-TEMPO was able to prevent the increase of both VEGF expression} and capillary length induced by chlordecone

To support the critical role of mitochondrial $\mathrm{O}_{2}{ }^{-}$- production in the proangiogenic effect of chlordecone, we monitored the consequence of Mito-TEMPO pretreatment on VEFG and capillary length formation. As shown in Fig. 8A and B, mito-TEMPO did not have an effect when added alone but it was able to prevent the increase of both VEGF expression and capillary length induced by chlordecone $\left(2 \times 10^{-11} \mathrm{M}\right.$ and $\left.5 \times 10^{-8} \mathrm{M}\right)$. The result confirms the importance of mitochondrial $\mathrm{O} 2-$ production in the signaling pathway.

\subsection{Estrogen receptor activation is involved in all effects of chlordecone}

Estrogen receptor is a key target involved in the angiogenesis induced by chlordecone as we recently reported (Clere et al., 2012). Therefore, we next questioned whether the chlordecone effects observed on the mitochondrial capacity, cellular and mitochondrial $\mathrm{O}_{2} \cdot{ }^{-}$ production were also related to ER activation. All the effects were not observed in the presence of the ER-antagonist fulvestrant (Fig. 9A-F) suggesting that estrogen receptor activation is probably the underlying mechanism of the chlordecone effects.

\section{Discussion}

In the present study, we provide evidence that a redox crosstalk between NADPH oxidase and mitochondria is involved in the proangiogenic activity of chlordecone. Most in detail, chlordecone induces angiogenesis via a sequential increase of $02^{-}{ }^{-}$from NADPH oxidase which in turn activates NO pathway leading to enhance mitochondrial $\mathrm{O}_{2} \cdot{ }^{-}$production. All of these effects concur to increase VEGF and capillary formation. Of particular interest is the confirmation that chlordecone mediates its effect via ER.

Even though the contribution of endothelial glycolysis to angiogenesis is major, several recent studies have coupled angiogenesis and mitochondrial function. For example, in mice muscle, surexpression of PGC1 $\alpha$-b promotes mitochondrial biogenesis and enhances angiogenesis (Tadaishi et al., 2011). Here we showed that mitochondrial biogenesis is not required for chlordecone induced angiogenesis as low concentration of chlordecone caused a marked increase in capillary length without any significant change of mitochondrial respiration. Nonetheless, we observed an adaptation of oxidative metabolismat with at low chlordecone concentration a trend to an increase of FCCP stimulated respiration and above all at a high concentration a mitochondrial biogenesis. Given that VEGF signaling is known to stimulate mitochondrial biogenesis (Wright et al., 2008), it is possible that explanation of the differential effects is a higher mitochondrial ROS production induced by the high chlordecone concentration which may 

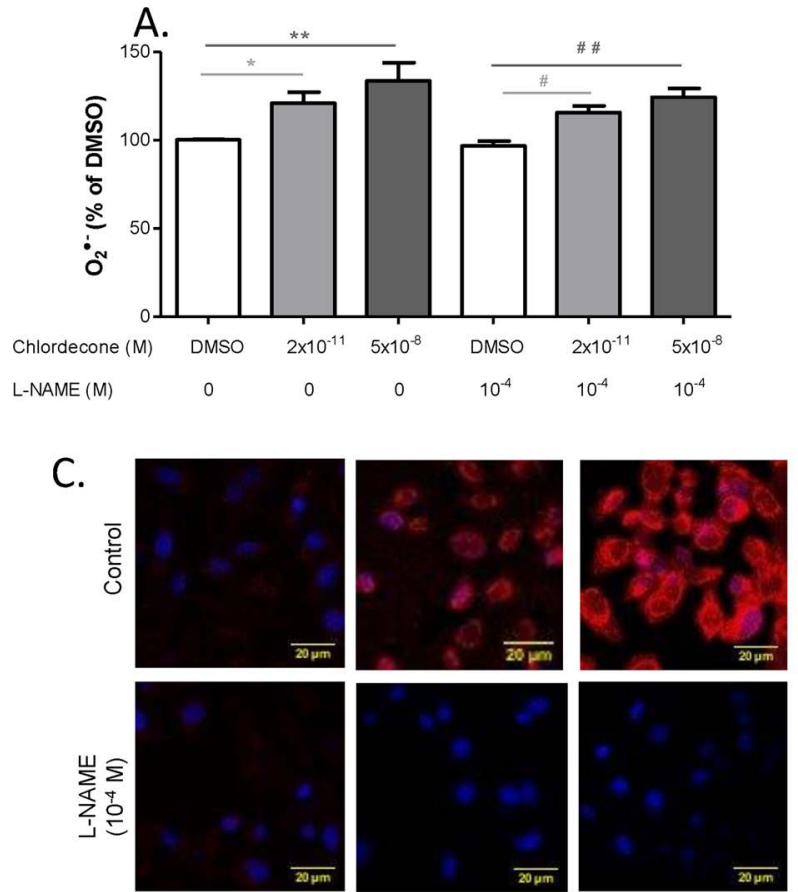

DMSO

$\left(2 \times 10^{-11}\right)$

Chlordecone (M)

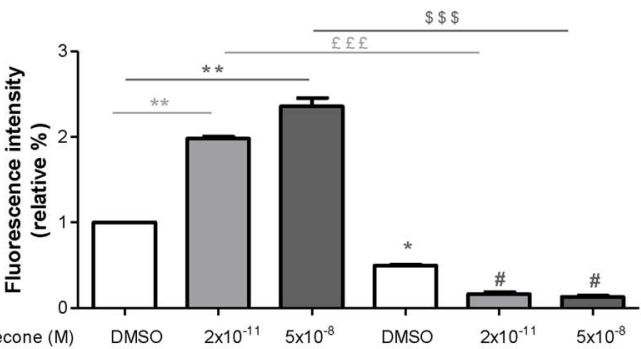

Chlordecone (M) DMSO $2 \times 10^{-11} \quad 5 \times 10^{-8} \quad$ DMSO $2 \times 10^{-11} \quad 5 \times 10^{-8}$ $\begin{array}{lllllll}\text { L-NAME (M) } & 0 & 0 & 0 & 10^{-4} & 10^{-4} & 10^{-4}\end{array}$

E.

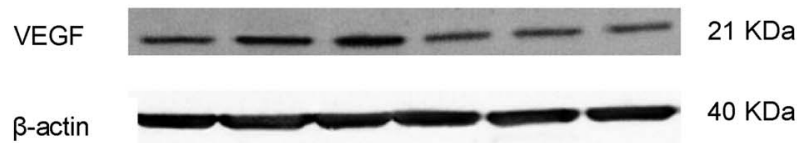

Chlordecone (M) DMSO $2 \times 10^{-11} \quad 5 \times 10^{-8} \quad$ DMSO $2 \times 10^{-11} \quad 5 \times 10^{-8}$

$\begin{array}{lllllll}\text { L-NAME (M) } & 0 & 0 & 0 & 10^{-4} & 10^{-4} & 10^{-4}\end{array}$

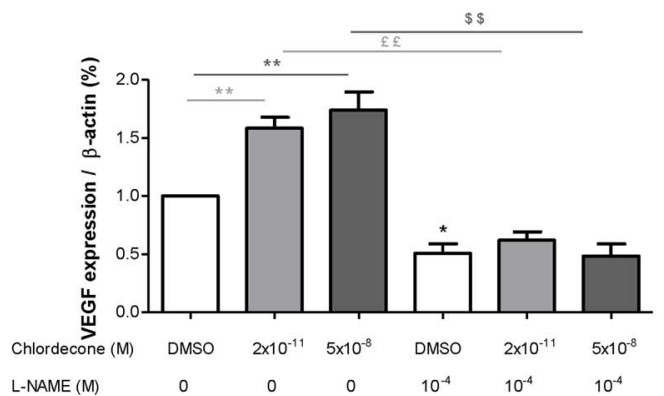

D.
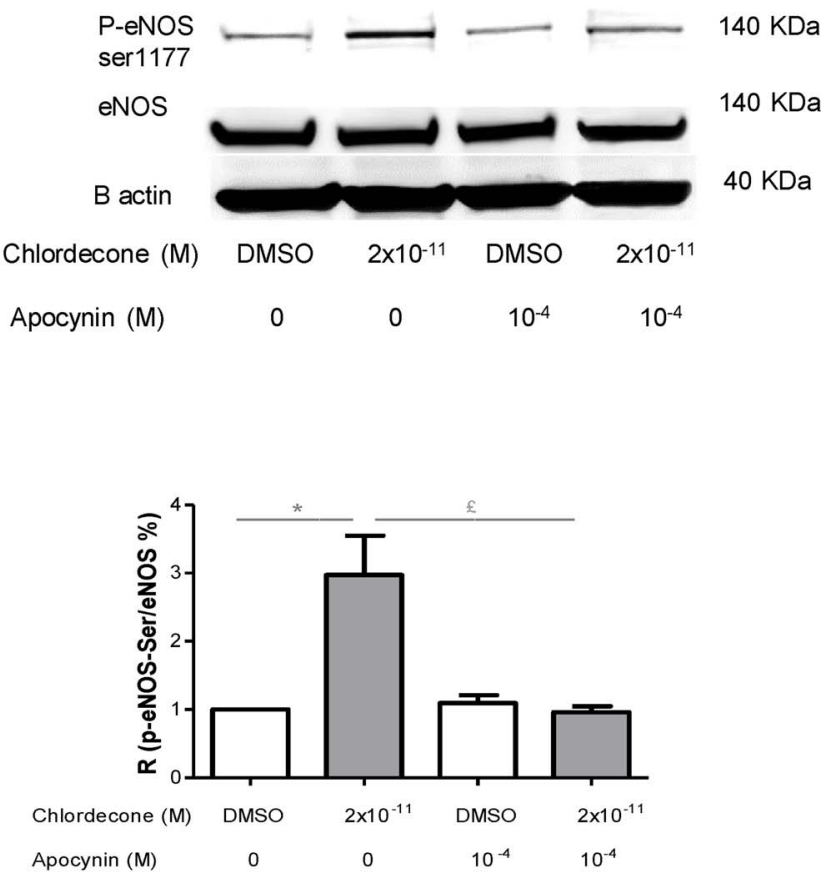

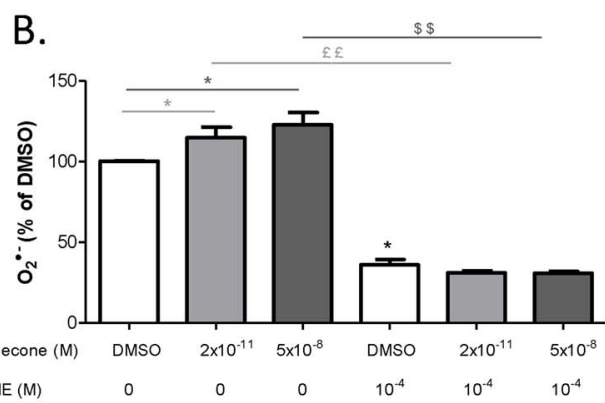

L-NAME (M)

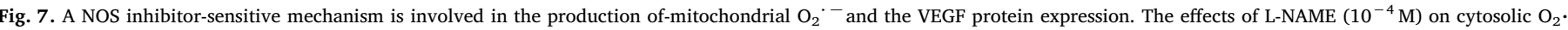

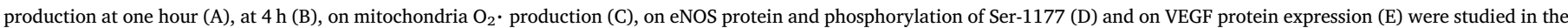

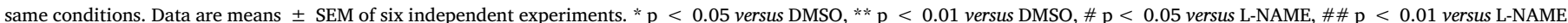

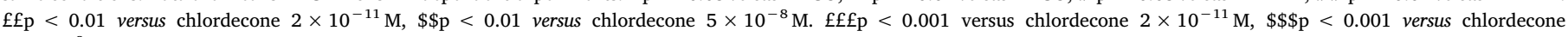
$5 \times 10^{-8} \mathrm{M}$ 
A.
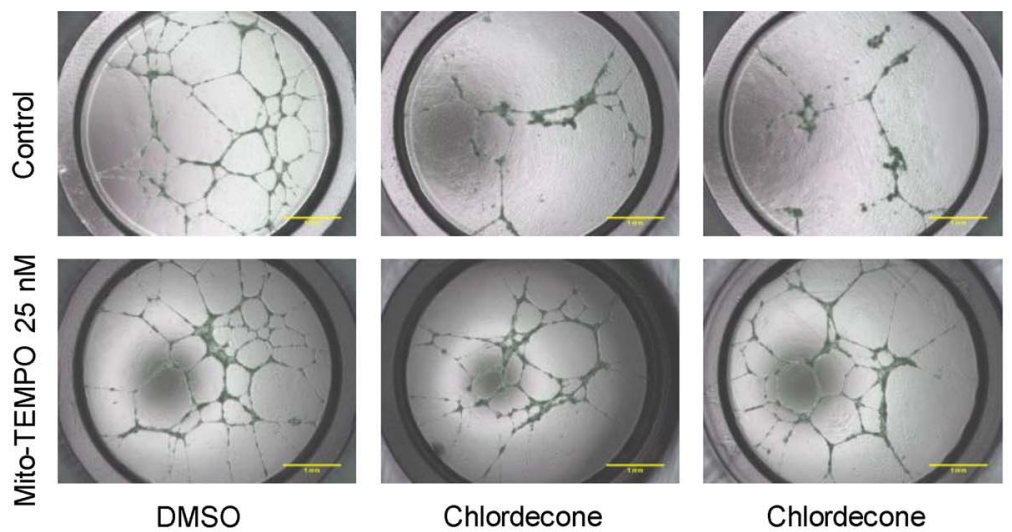

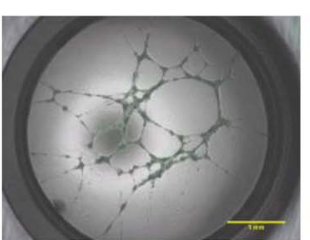

Chlordecone $\left(2 \times 10^{-11} \mathrm{M}\right)$

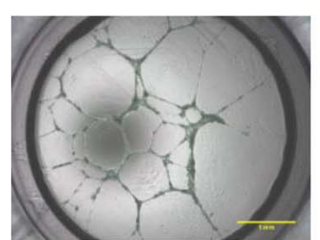

Chlordecone

$\left(5 \times 10^{-8} \mathrm{M}\right)$

$\$ \$$

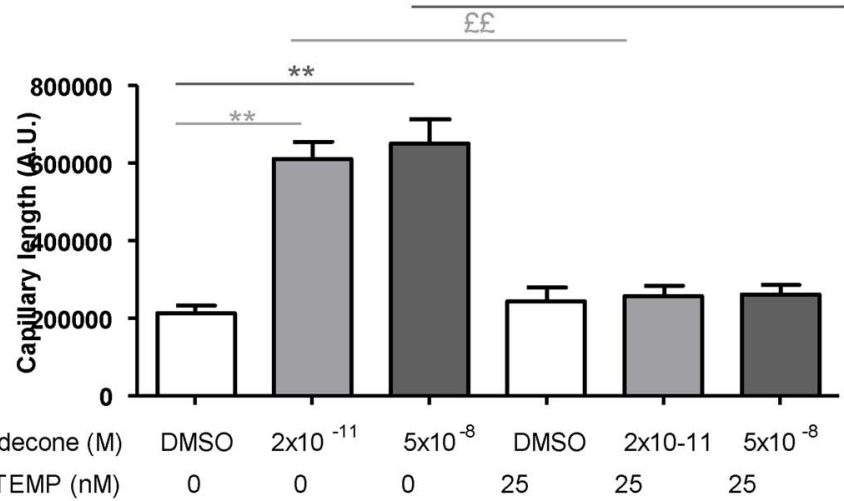

B.

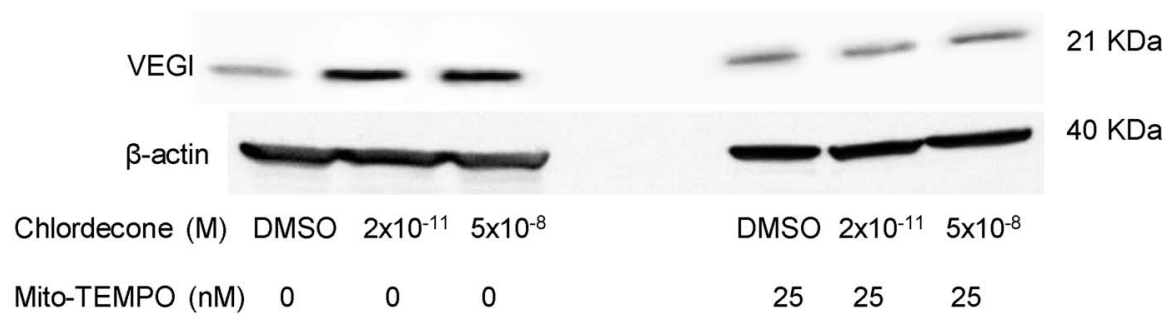

$\$$

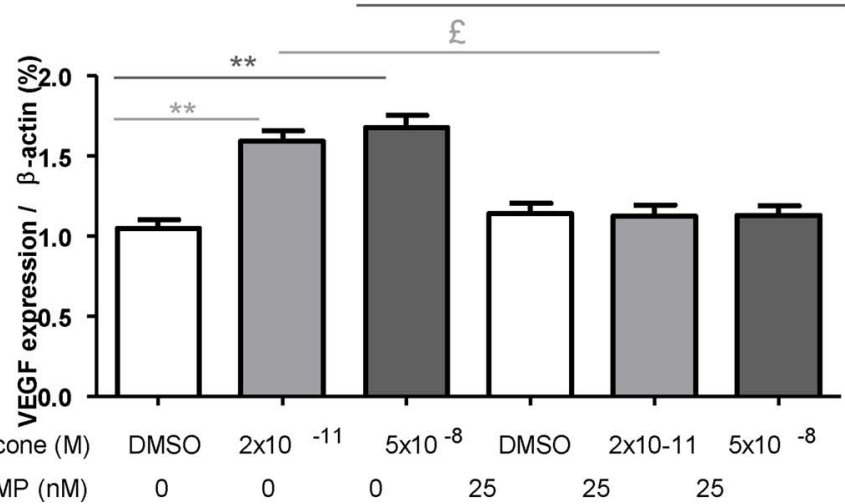

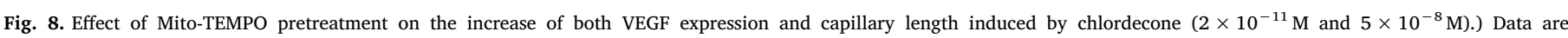

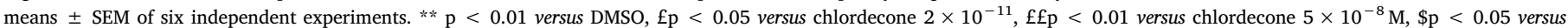
chlordecone $5 \times 10^{-11} \mathrm{M}, \$ \$ \mathrm{p}<0.01$ versus chlordecone $5 \times 10^{-8} \mathrm{M}$.

stimulate VEGF signaling in ECs. Conversely, in the condition of lower chlordecone concentration, since VEGF signaling was shown to be dispensable for the vessels formation, VEGF is susceptible to contribute only to cell survival in a way that is independent of surface ligand/ receptor interactions as proposed by Domigan (Domigan et al., 2015). Interestingly, it was suggested that in that case, VEGF maintains 

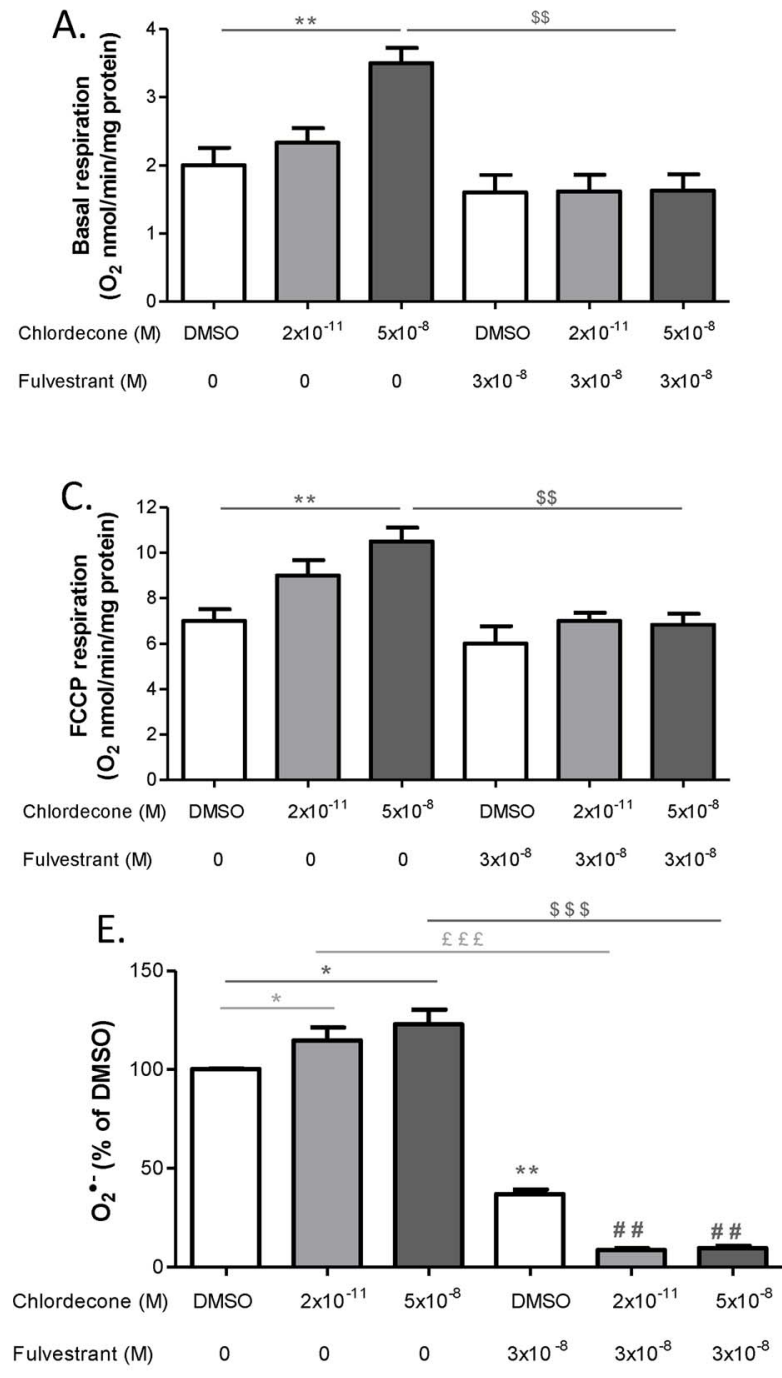

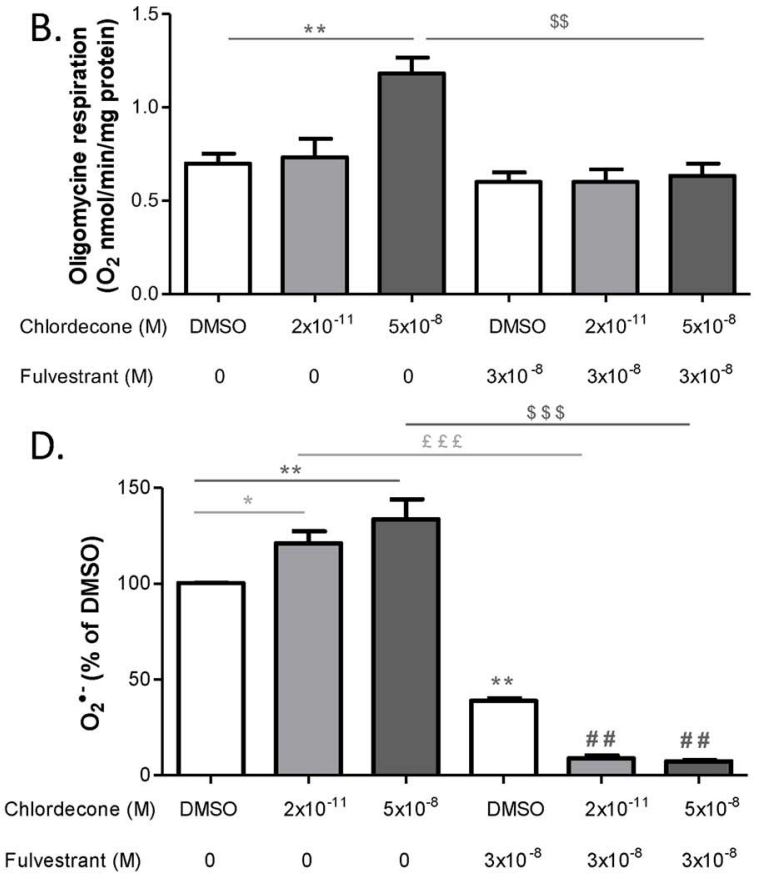

F.
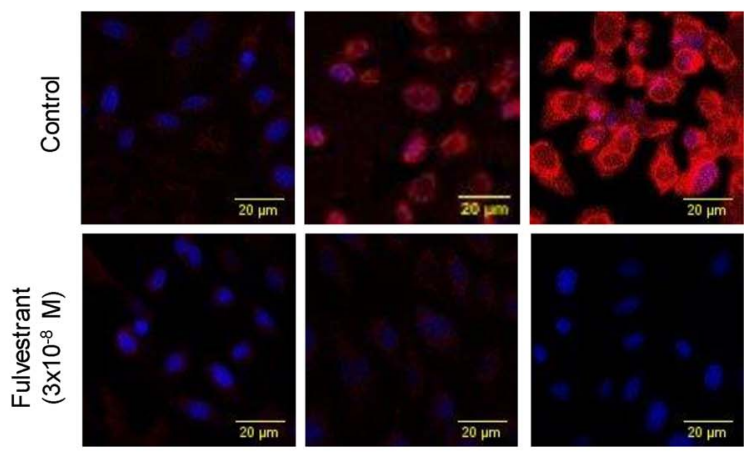

DMSO

$\left(2 \times 10^{-11}\right)$

$\left(5 \times 10^{-8}\right)$

Chlordecone (M) $\$ \$ \$$

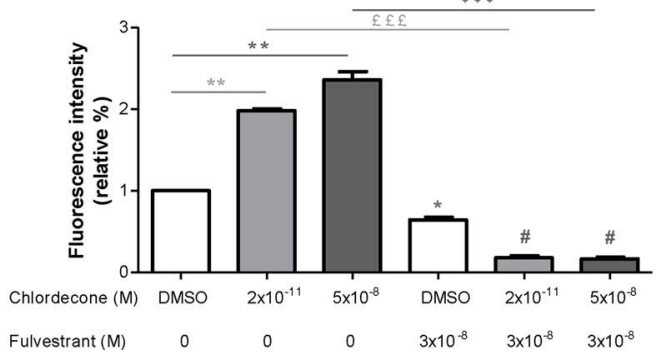

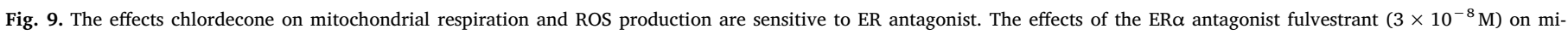

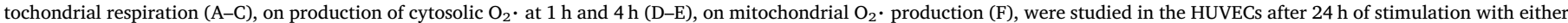

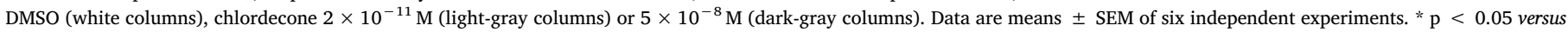

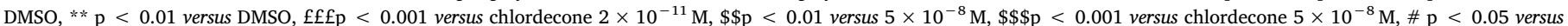
fulvestrant, \#\# $\mathrm{p}<0.01$ versus fulvestrant.

vascular homeostasis through regulation of the transcription factor FOXO1 levels. Moreover, it was recently reported that the energetic metabolic activity and growth state in the vascular endothelium may be coupled by the regulation of MYC through FOXO1 (Wilhelm et al., 2016). Remarkably, MYC overexpression stimulated both glycolysis and mitochondrial respiration. Involvement of MYC in the effect of low chlordecone concentration cannot be excluded and merits further investigation.

Besides the energetic role, a mitochondrial redox signaling stimulated by an initial cytosolic $\mathrm{O}_{2}{ }^{-}-$production appears to be determinant in the proangiogenic effect irrespective of chlordecone concentration. Indeed, intracellular pathways involved in the effect of chlordecone show differential spatial and temporal regulation with respect to cytosolic and mitochondrial pools of ROS.

In EC, cytoplasmic ROS can originate from several sources including NADPH oxidase, xanthine oxidase and eNOS. Our data indicate that the NADPH oxidase is the major site for the early $\mathrm{O}_{2}{ }^{-}$- production because apocynin and most importantly silencing RNA-mediated knockdown of 


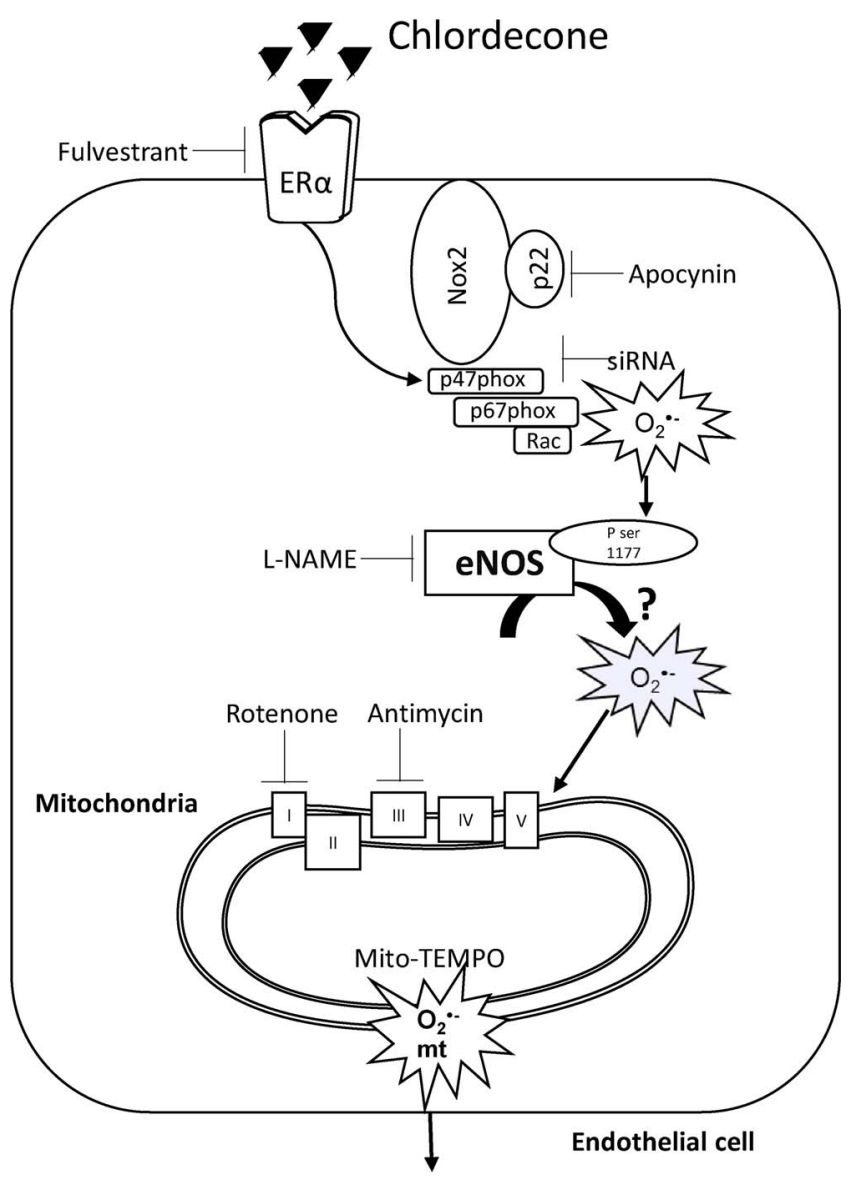

\section{Angiogenesis}

Fig. 10. Schematic diagram illustrating the chlordecone induced proangiogenic effect via $\mathrm{ER} \alpha$ and redox signaling and indicating the molecular target of the different inhibitors used in the study.

$\mathrm{p} 47^{\text {phox }}$, an organizer subunit for Nox2/Nox1 (Drummond and Sobey, 2014) prevents the generation of $\mathrm{O}_{2}{ }^{-}$. In addition, the early increase on cytosolic ROS production was also prevented by rotenone and antimycin. The explanation for this is not clear and more work will be required to more fully understand the consequence of inhibition of the respiratory chain on NADPH oxidase activity. Whatever the exact mechanism underlying NADPH oxidase activation, NADPH oxidase ROS production is as an important event as confirmed by the negative effect of apocynin on VEGF expression and capillary formation. We are aware of the fact that apocynin, a widely used inhibitor of NADPH is quite non specific. Nevertheless, the fact that silencing p47 which is one of the master subunit of NADPH linked to Nox-2 exhibits similar effects than apocynin on the early increase in ROS production supports the involvement of at least Nox-2 in the pathway This critical role of Nox1 or Nox2 has been previously reported in both physiological and pathological angiogenesis (Kim and Byzova, 2014; Ushio-Fukai, 2007). NADPH oxidase derived ROS were demonstrated to be an important mediator to promote revascularization in an experimental ischemic hindlimb model (Urao et al., 2013) as well as to facilitate the retinal VEGF expression and neovascularization in a model of oxygen induced retinopathy in mice (Chan et al., 2013). In addition, it was reported that neovascularization in response to ischemia is inhibited in NOX2-/- mice and in wild type mice treated with NADPH inhibitor apocynin. Collectively, these data underline the importance of Nox2/Nox1 Nonetheless; we cannot exclude the possibility that the co expressed in endothelial cells Nox4 may also be involved. In line with that, Nox isoform Nox4 were shown to stimulate mtROS production (Ago et al., 2010) and it was recently reported that Nox4 can promote tumor angiogenesis (Helfinger et al., 2016). Additional work is needed to determine the possible interaction of these two NADPH oxidase isoforms in the chlordecone induced angiogenesis.

Mitochondria are responsible for late-phase ROS production. Inhibition of mitochondrial $\mathrm{O}_{2} \cdot{ }^{-}$production by apocynin and siRNA $\mathrm{p} 47^{\text {phox }}$ demonstrates an upstream role of NADPH oxidase in the activation of mitochondrial ROS. In addition, our data indicate that a more direct downstream target of NADPH oxidase $\mathrm{O}_{2}{ }^{-}{ }^{-}$is most probably eNOS. Indeed, L-NAME, an inhibitor of NOS, totally prevented mitochondrial ROS production and angiogenesis without inhibiting the production of $\mathrm{O}_{2}{ }^{-}$- from NADPH oxidase. Moreover the effect occurred at $1 \mathrm{~h}$ exposure with chlordecone, a time at which the induction of iNOS is unlikely. In this redox signaling pathway, NOS appears to be a target of NADPH oxidase since apocynin pre-treatment was shown to decrease eNOS phosphorylation on its positive regulatory site (Ser 1177). Consistent with these results, data in the literature including our previous works on the effects of red wine polyphenol have reported activation of eNOS by ROS generated by NADPH oxidase (Ndiaye et al., 2003; Duarte et al., 2004; Duluc et al., 2013). In line also with these observations, it has recently been shown that angiotensin II stimulation in cardiac myocytes leads to the activation of NADPH oxidase which in turn activates Akt and phosphorylates eNOS on the same positive regulatory site (Jang et al., 2015). Thus, activation of NOS by serine 1177 phosphorylation could be a physiological response to an acute increase in oxidative stress under normal conditions as suggested by Rafikov. (Rafikov et al., 2011). The mechanism by which activation of NOS increase mitochondrial ROS production has not been investigated in the present work but might be related to uncoupling of eNOS, activation of the redox sensitive PKCe, opening of mitochondrial $\mathrm{K}_{\mathrm{ATP}}$ and subsequent ROS formation secondary to matrix alkalization as reported in various pathophysiological situations involving mitochondrial redox signaling (Dikalov et al., 2014a; Malinska et al., 2010). The proposal mechanism is in line with recent study pointing to the requirement of NO synthase in activating PKC $\varepsilon$ to increase VEGF level in abnormal angiogenesis of diabetic retinopathy (Zhang et al., 2015).

The findings presented here suggest that the mitochondrial $\mathrm{O}_{2}{ }^{-}$ production contribute to increased VEGF expression. Downstream of mitochondrial $\mathrm{O}_{2}{ }^{-}$production, various redox sensitive mechanisms that involve translational regulation of VEGF have been described. For example in hypoxia, $\mathrm{O}_{2}{ }^{-}$generated from mitochondria clustering in close proximity to the nucleus hypoxia has been shown to stimulate VEGF expression by increasing the binding of HIF-1 to VEGF promoter via oxidative DNA modification (Al-Mehdi et al., 2012). Another mitochondrial ROS sensitive mechanism that has often been proposed to regulate VEGF translation involves activation of the proangiogenic transcription factor HIF1 (Chang et al., 2014; Hagen, 2012). This increased VEGF expression is expected to drive the angiogenic process. However, several studies have reported ROS activated angiogenesis operating in a VEGF independent manner (Kim and Byzova, 2014). As discussed above, the latter possibility seems plausible at least for the effect of low chlodecone concentration. Clearly, the role of VEGF in the chlordecone induced angiogenesis merits further investigation.

Very recently, we reported temporal cross talk between ER and mitochondria with respect to spatial regulation of $\mathrm{O}_{2} \cdot{ }^{-}$via the neutral sphyngomyelinase in response to microparticles (Safiedeen et al., 2017). In the later, this mechanism concurs to endothelial dysfunction. In the present study, such temporal regulation of oxidative stress is highlighted and this leads to pro-angiogenic response with regard to chlordecone. The differential response probably is related to upstream regulation of mitochondrial ROS: i.e. for microparticles, ER stress is implicated whereas for chlordecone NADPH oxidase and eNOS pathway are involved. 


\section{Conclusions}

In summary, we demonstrate that chlordecone induces angiogenesis by regulating the production of mitochondrial $\mathrm{O}_{2}{ }^{-}$via both NADPH oxidase and NO sensitive pathways (Fig. 10). The chlordecone induced angiogenesis might be causally implicated in the growing incidence of prostate cancer in Martinique. (Multigner et al., 2010). Indeed, in this cancer, the process of angiogenesis, generally referred to as the "angiogenic switch" is critical for sustained tumor growth and metastasis (Huss et al., 2001). Even if chlordecone is probably not the key element in this switch, it may create an imbalance favoring proangiogenic stimuli. Therefore, targeting the pathway involved in the angiogenic effect of chlordecone pathway could be suitable to manage men with prostate cancer and high plasma chlordecone concentrations.

\section{Conflict of interest}

The authors have no conflicts of interest to disclose.

\section{Acknowledgement}

The authors wish to thank Isabelle Brunois Debu for the reading of the manuscript.

\section{References}

Ago, T., Kuroda, J., Pain, J., Fu, C., Li, H., Sadoshima, J., 2010. Upregulation of Nox4 by hypertrophic stimuli promotes apoptosis and mitochondrial dysfunction in cardiac myocytes. Circ. Res. 106, 1253-1264. http://dx.doi.org/10.1161/CIRCRESAHA.109. 213116.

Al-Mehdi, A.-B., Pastukh, V.M., Swiger, B.M., Reed, D.J., Patel, M.R., Bardwell, G.C., Pastukh, V.V., Alexeyev, M.F., Gillespie, M.N., 2012. Perinuclear mitochondrial clustering creates an oxidant-rich nuclear domain required for hypoxia-induced transcription. Sci. Signal. 5, ra47. http://dx.doi.org/10.1126/scisignal.2002712.

Band, P.R., Abanto, Z., Bert, J., Lang, B., Fang, R., Gallagher, R.P., Le, N.D., 2011. Prostate cancer risk and exposure to pesticides in British Columbia Farmers. Prostate 71, 168-183. http://dx.doi.org/10.1002/pros.21232.

Cantelmo, A.R., Brajic, A., Carmeliet, P., 2015. Endothelial metabolism driving angiogenesis: emerging concepts and principles. Cancer J. Sudbury Mass 21, 244-249. http://dx.doi.org/10.1097/PPO.0000000000000133.

Chan, E.C., van Wijngaarden, P., Liu, G.-S., Jiang, F., Peshavariya, H., Dusting, G.J., 2013. Involvement of Nox2 NADPH oxidase in retinal neovascularization. Invest. Ophthalmol. Vis. Sci. 54, 7061-7067. http://dx.doi.org/10.1167/iovs.13-12883.

Chang, J., Jung, H.J., Jeong, S.H., Kim, H.K., Han, J., Kwon, H.J., 2014. A mutation in the mitochondrial protein UQCRB promotes angiogenesis through the generation of mitochondrial reactive oxygen species. Biochem. Biophys. Res. Commun. 455, 290-297. http://dx.doi.org/10.1016/j.bbrc.2014.11.005.

Clere, N., Lauret, E., Malthiery, Y., Andriantsitohaina, R., Faure, S., 2012. Estrogen receptor alpha as a key target of organochlorines to promote angiogenesis. Angiogenesis 15, 745-760. http://dx.doi.org/10.1007/s10456-012-9288-7.

De Bock, K., Georgiadou, M., Schoors, S., Kuchnio, A., Wong, B.W., Cantelmo, A.R., Quaegebeur, A., Ghesquière, B., Cauwenberghs, S., Eelen, G., Phng, L.-K., Betz, I., Tembuyser, B., Brepoels, K., Welti, J., Geudens, I., Segura, I., Cruys, B., Bifari, F., Decimo, I., Blanco, R., Wyns, S., Vangindertael, J., Rocha, S., Collins, R.T., Munck, S., Daelemans, D., Imamura, H., Devlieger, R., Rider, M., Van Veldhoven, P.P., Schuit, F., Bartrons, R., Hofkens, J., Fraisl, P., Telang, S., Deberardinis, R.J., Schoonjans, L., Vinckier, S., Chesney, J., Gerhardt, H., Dewerchin, M., Carmeliet, P., 2013. Role of PFKFB3-driven glycolysis in vessel sprouting. Cell 154, 651-663. http://dx.doi.org/ 10.1016/j.cell.2013.06.037.

Dikalov, S.I., Nazarewicz, R.R., Bikineyeva, A., Hilenski, L., Lassègue, B., Griendling, K.K., Harrison, D.G., Dikalova, A.E., 2014a. Nox2-induced production of mitochondrial superoxide in angiotensin II-mediated endothelial oxidative stress and hypertension. Antioxid. Redox Signal. 20, 281-294. http://dx.doi.org/10.1089/ars.2012.4918.

Dikalov, S.I., Nazarewicz, R.R., Bikineyeva, A., Hilenski, L., Lassègue, B., Griendling, K.K., Harrison, D.G., Dikalova, A.E., 2014b. Nox2-induced production of mitochondrial superoxide in angiotensin II-mediated endothelial oxidative stress and hypertension. Antioxid. Redox Signal. 20, 281-294. http://dx.doi.org/10.1089/ars.2012.4918.

Dikalov, S., 2011. Cross talk between mitochondria and NADPH oxidases. Free Radic. Biol. Med. 51, 1289-1301. http://dx.doi.org/10.1016/j.freeradbiomed.2011.06.033.

Domigan, C.K., Warren, C.M., Antanesian, V., Happel, K., Ziyad, S., Lee, S., Krall, A. Duan, L., Torres-Collado, A.X., Castellani, L.W., Elashoff, D., Christofk, H.R., van der Bliek, A.M., Potente, M., Iruela-Arispe, M.L., 2015. Autocrine VEGF maintains endothelial survival through regulation of metabolism and autophagy. J. Cell Sci. 128, 2236-2248. http://dx.doi.org/10.1242/jcs.163774.

Doughan, A.K., Harrison, D.G., Dikalov, S.I., 2008. Molecular mechanisms of angiotensin II-mediated mitochondrial dysfunction: linking mitochondrial oxidative damage and vascular endothelial dysfunction. Circ. Res. 102, 488-496. http://dx.doi.org/10. 1161/CIRCRESAHA.107.162800.
Drummond, G.R., Sobey, C.G., 2014. Endothelial NADPH oxidases: which NOX to target in vascular disease? Trends Endocrinol. Metab. TEM 25, 452-463. http://dx.doi.org/ 10.1016/j.tem.2014.06.012.

Duarte, J., Andriambeloson, E., Diebolt, M., Andriantsitohaina, R., 2004. Wine polyphenols stimulate superoxide anion production to promote calcium signaling and endothelial-dependent vasodilatation. Physiol. Res. Acad. Sci. Bohemoslov. 53, 595-602.

Duluc, L., Jacques, C., Soleti, R., Iacobazzi, F., Simard, G., Andriantsitohaina, R., 2013. Modulation of mitochondrial capacity and angiogenesis by red wine polyphenols via estrogen receptor, NADPH oxidase and nitric oxide synthase pathways. Int. J. Biochem. Cell Biol. 45, 783-791. http://dx.doi.org/10.1016/j.biocel.2013.01.007.

Eelen, G., Cruys, B., Welti, J., De Bock, K., Carmeliet, P., 2013. Control of vessel sprouting by genetic and metabolic determinants. Trends Endocrinol. Metab. TEM 24, 589-596. http://dx.doi.org/10.1016/j.tem.2013.08.006.

Frey, R.S., Ushio-Fukai, M., Malik, A.B., 2009. NADPH oxidase-dependent signaling in endothelial cells: role in physiology and pathophysiology. Antioxid. Redox Signal. 11, 791-810. http://dx.doi.org/10.1089/ARS.2008.2220.

Hagen, T., 2012. Oxygen versus reactive oxygen in the regulation of HIF-1 $\alpha$ : the balance tips. Biochem. Res. Int. 2012, 436981. http://dx.doi.org/10.1155/2012/436981.

Helfinger, V., Henke, N., Harenkamp, S., Walter, M., Epah, J., Penski, C., Mittelbronn, M., Schröder, K., 2016. The NADPH oxidase Nox4 mediates tumour angiogenesis. Acta Physiol. Oxf. Engl. 216, 435-446. http://dx.doi.org/10.1111/apha.12625.

Hillon, P., Guiu, B., Vincent, J., Petit, J.-M., 2010. Obesity, type 2 diabetes and risk of digestive cancer. Gastroentérol. Clin. Biol. 34, 529-533. http://dx.doi.org/10.1016/j. gcb.2010.07.021.

Huss, W.J., Hanrahan, C.F., Barrios, R.J., Simons, J.W., Greenberg, N.M., 2001. Angiogenesis and prostate cancer: identification of a molecular progression switch. Cancer Res. 61, 2736-2743.

Jang, J.H., Chun, J.N., Godo, S., Wu, G., Shimokawa, H., Jin, C.Z., Jeon, J.H., Kim, S.J., Jin, Z.H., Zhang, Y.H., 2015. ROS and endothelial nitric oxide synthase (eNOS)-dependent trafficking of angiotensin II type 2 receptor begets neuronal NOS in cardiac myocytes. Basic Res. Cardiol. 110 (21). http://dx.doi.org/10.1007/s00395-0150477-6.

Johnson, D.K., Schillinger, K.J., Kwait, D.M., Hughes, C.V., McNamara, E.J., Ishmael, F., O’Donnell, R.W., Chang, M.M., Hogg, M.G., Dordick, J.S., Santhanam, L., Ziegler, L.M., Holland, J.A., 2002. Inhibition of NADPH oxidase activation in endothelial cells by ortho-methoxy-substituted catechols. Endothelium 9, 191-203.

Kim, Y.-W., Byzova, T.V., 2014. Oxidative stress in angiogenesis and vascular disease. Blood 123, 625-631. http://dx.doi.org/10.1182/blood-2013-09-512749.

Kluge, M.A., Fetterman, J.L., Vita, J.A., 2013. Mitochondria and endothelial function. Circ. Res. 112, 1171-1188. http://dx.doi.org/10.1161/CIRCRESAHA.111.300233.

Li, Y.-N., Xi, M.-M., Guo, Y., Hai, C.-X., Yang, W.-L., Qin, X.-J., 2014. NADPH oxidasemitochondria axis-derived ROS mediate arsenite-induced HIF-1 $\alpha$ stabilization by inhibiting prolyl hydroxylases activity. Toxicol. Lett. 224, 165-174. http://dx.doi. org/10.1016/j.toxlet.2013.10.029.

Lugus, J.J., Ngoh, G.A., Bachschmid, M.M., Walsh, K., 2011. Mitofusins are required for angiogenic function and modulate different signaling pathways in cultured endothelial cells. J. Mol. Cell. Cardiol. 51, 885-893. http://dx.doi.org/10.1016/j. yjmcc.2011.07.023.

Malinska, D., Mirandola, S.R., Kunz, W.S., 2010. Mitochondrial potassium channels and reactive oxygen species. FEBS Lett. 584, 2043-2048. http://dx.doi.org/10.1016/j. febslet.2010.01.013.

Miller, R.W., 2004. How environmental hazards in childhood have been discovered: carcinogens, teratogens, neurotoxicants, and others. Pediatrics 113, 945-951.

Mostefai, H.A., Agouni, A., Carusio, N., Mastronardi, M.L., Heymes, C., Henrion, D., Andriantsitohaina, R., Martinez, M.C., 2008. Phosphatidylinositol 3-Kinase and xanthine oxidase regulate nitric oxide and reactive oxygen species productions by apoptotic lymphocyte microparticles in endothelial cells. J. Immunol. 180, 5028-5035. http://dx.doi.org/10.4049/jimmunol.180.7.5028.

Multigner, L., Ndong, J.R., Giusti, A., Romana, M., Delacroix-Maillard, H., Cordier, S., Jégou, B., Thome, J.P., Blanchet, P., 2010. Chlordecone exposure and risk of prostate cancer. J. Clin. Oncol. 28, 3457-3462. http://dx.doi.org/10.1200/JCO.2009.27. 2153.

Ndiaye, M., Chataigneau, T., Andriantsitohaina, R., Stoclet, J.-C., Schini-Kerth, V.B., 2003. Red wine polyphenols cause endothelium-dependent EDHF-mediated relaxations in porcine coronary arteries via a redox-sensitive mechanism. Biochem. Biophys. Res. Commun. 310, 371-377.

Rafikov, R., Fonseca, F.V., Kumar, S., Pardo, D., Darragh, C., Elms, S., Fulton, D., Black, S.M., 2011. eNOS activation and NO function: structural motifs responsible for the posttranslational control of endothelial nitric oxide synthase activity. J. Endocrinol. 210, 271-284. http://dx.doi.org/10.1530/JOE-11-0083.

Risau, W., 1997. Mechanisms of angiogenesis. Nature 386, 671-674. http://dx.doi.org/ 10.1038/386671a0.

Safiedeen, Z., Rodríguez-Gómez, I., Vergori, L., Soleti, R., Vaithilingam, D., Douma, I., Agouni, A., Leiber, D., Dubois, S., Simard, G., Zibara, K., Andriantsitohaina, R., Martínez, M.C., 2017. Temporal cross talk between endoplasmic reticulum and mitochondria regulates oxidative stress and mediates microparticle-Induced endothelial dysfunction. Antioxid. Redox Signal. 26 (January (1)), 15-27. http://dx.doi.org/10. 1089/ars.2016.6771.

Shakeel, M.K., George, P.S., Jose, J., Jose, J., Mathew, A., 2010. Pesticides and breast cancer risk: a comparison between developed and developing countries. Asian Pac. J. Cancer Prev. APJCP 11, 173-180.

Shchepinova, A.G., Cairns, T.A., Prime, A., Logan, A.M., James, A.R., Hall, S., Vidoni, S., Arndt, S.T., Caldwell, H.A., Prag, V.R., Pell, T., Krieg, J.F., Mulvey, P., Yadav, J.N., Cobley, T.P., Bright, H.M., Senn, R.F., Anderson, M.P., Murphy, R.C., 2017. MitoNeoD a mitochondria-targeted superoxide probe. Cell Chem. Biol. 19;24 
(October (10)), 1285-1298. e12. http://dx.doi.org/10.1016/j.chembiol.2017.08. 003. Epub 2017 Sep 7.

Tadaishi, M., Miura, S., Kai, Y., Kano, Y., Oishi, Y., Ezaki, O., 2011. Skeletal musclespecific expression of PGC-1 $\alpha$-b, an exercise-responsive isoform, increases exercise capacity and peak oxygen uptake. PLoS One 6 (12), e28290. http://dx.doi.org/10. 1371/journal.pone.0028290.

Urao, N., Sudhahar, V., Kim, S.-J., Chen, G.-F., McKinney, R.D., Kojda, G., Fukai, T., Ushio-Fukai, M., 2013. Critical role of endothelial hydrogen peroxide in post-ischemic neovascularization. PLoS One 8, e57618. http://dx.doi.org/10.1371/journal. pone.0057618.

Ushio-Fukai, M., 2006. Redox signaling in angiogenesis: role of NADPH oxidase.

Cardiovasc. Res. 71, 226-235. http://dx.doi.org/10.1016/j.cardiores.2006.04.015.

Ushio-Fukai, M., 2007. VEGF signaling through NADPH oxidase-derived ROS. Antioxid.
Redox Signal. 9, 731-739. http://dx.doi.org/10.1089/ars.2007.1556.

Wilhelm, K., Happel, K., Eelen, G., Schoors, S., Oellerich, M.F., Lim, R., Zimmermann, B., Aspalter, I.M., Franco, C.A., Boettger, T., Braun, T., Fruttiger, M., Rajewsky, K., Keller, C., Brüning, J.C., Gerhardt, H., Carmeliet, P., Potente, M., 2016. FOXO1 couples metabolic activity and growth state in the vascular endothelium. Nature 529, 216-220. http://dx.doi.org/10.1038/nature16498.

Wright, G.L., Maroulakou, I.G., Eldridge, J., Liby, T.L., Sridharan, V., Tsichlis, P.N., Muise-Helmericks, R.C., 2008. VEGF stimulation of mitochondrial biogenesis: requirement of AKT3 kinase. FASEB J. 22, 3264-3275. http://dx.doi.org/10.1096/fj. 08-106468.

Zhang, Q., Jiang, Y., Steinle, J.J., 2015. IGFBP-3 reduces eNOS and PKCzeta phosphorylation, leading to lowered VEGF levels. Mol. Vis. 21, 604-611. 